\title{
Razão, religião e revolução: luzes e sombras nas telas de Jacques-Louis David
}

\section{Claudio Aguiar Almeida ${ }^{1}$}

RESUMO: $\bigcirc$ artigo analisa a produção pictórica de Jacques-Lovis David entre o final da década de 1770 e 1793, destacando o entrelaçamento entre arte, religião e política nas obras do artista francês. Em sua luta contra ○ Antigo Regime, "filósofos artistas", como Jacques-Lovis David, apossaram-se das armas que eram manipuladas, há séculos, por um de seus principais inimigos: a lgreja. A transmissão do ideário iluminista não poderia ficar restrita à "aridez" dos textos acadêmicos, devendo buscar na religião e nas artes o "encantamento" indispensável à conquista de olhos, ouvidos, cérebros e corações. Depois de recorrer aos heróis das antigas Grécia e Roma, Jacques-Louis David debruçou-se sobre os homens do seu tempo: os deputados de $\bigcirc$ juramento do jogo de pela e os mártires que sacrificaram suas vidas em prol da revolução. Entrelaçando a arte clássica com a cristã, razão, revolução e religião, Jacques-Lovis David forjou estratégias que seriam mobilizadas na propagação de líderes e ideários políticos nos séculos XIX e XX.

PALAVRAS-CHAVE: Jacques-Louis David. Revolução Francesa. Arte e política.

ABSTRACT: The article analyzes the pictorial production of Jacques-Louis David between the late 1770s and 1793, highlighting the links between art, religion and politics in the works of the French artist. In their struggle against the Old Regime "philosophers artists," as Jacques-Louis David, they took possession of the weapons that were manipulated for centuries by one of its main enemies: the Church. The transmission of Enlightenment ideas could not be restricted to "aridity" of academic papers and should seek in religion and the arts the "enchantment" indispensable to the conquest of eyes, ears, brains and hearts. After resorting to the heroes of ancient Greece and Rome, Jacques-Louis David leaned across the men of his time: the deputies of Tennis Court Oath and the martyrs who sacrificed their lives for the sake of revolution. Interweaving classical art with Christian art, reason, revolution and religion, Jacques-Louis David forged strategies that would be mobilized in the spread of political leaders and ideologies in the nineteenth and twentieth centuries.
1. Doutor pelo Programa de Pós-graduação em História Social da Faculdade de Filosofia, Letras e Ciências Humanas (FFLCH) da Universidade de São Paulo (USP). Professor do Centro Universitário Fundação Instituto de Ensino para Osasco - Unifieo (1994/2013) e do curso de Pós-graduação "História da Arte: teoria e crítica" da Faculdade Belas Artes de São Paulo (2013/2015). E-mail: <caguiaralmeida@ gmail.com>.

KEYWORDS: Jacques-Louis David. French Revolution. Art and Politics. 
A análise do entrelaçamento entre arte, religião e política nas obras de Jacques-Louis David exige que nos debrucemos, ainda que de forma breve, sobre os adversários que o artista pretendia combater, o absolutismo e a lgreja Católica, bem como sobre a doutrina que the forneceu alguns dos instrumentos para esse embate: o lluminismo.

\section{absolutismo}

A Fonte de Latona, em Versalhes, nos informa não apenas sobre o mito que lhe dá nome, mas também sobre a construção do palácio que ela ornamenta. Extremamente bela, Latona atraiu a atenção de Júpiter, com quem gerou dois filhos: Apolo e Ártemis. Ciente do ocorrido, Juno, esposa de Júpiter, incitou camponeses a perseguir Latona, obrigando-a a fugir com seus filhos. A fonte remete-se a um dos momentos dessa perseguição quando, alcançada enquanto matava sua sede num riacho, Latona foi salva pela intervenção de Júpiter, que transformou os camponeses que a perseguiam em sapos.

A escolha da cena descrita tem relação direta com a construção do palácio. Nascido em 1638, o futuro Luís XIV não tinha maturidade suficiente para assumir o trono no momento da morte de seu pai, em 1643. Auxiliada pelo cardeal Mazarin, Ana da Áustria assumiu a regência da França, dando continuidade à política de concentração de poderes iniciada por Luís XIII. Incomodados pelo crescimento do poder real, os nobres franceses promoveram uma série de revoltas entre 1648 e 1653, obrigando Ana da Áustria e seu filho a fugirem de Paris. Anos mais tarde, na região da cabana de caça que abrigara a família real durante a Rebelião da Fronda, Luís XIV ergueu o suntuoso Palácio de Versalhes: uma vez que não conseguia transformar seus opositores em sapos, Luís XIV decidiu mantê-los a uma distância segura, deslocando sua corte para fora de Paris.

Embora não fosse Júpiter, Luís XIV reunia poderes que o aproximavam dos deuses. Como outros monarcas do Antigo Regime, Luís XIV era tido como um representante de Deus na Terra. Essa perspectiva divina e sagrada em relação ao poder servia como argumento justificador dos poderes absolutistas dos monarcas franceses que, nas palavras do teórico Lebret, haviam recebido o seu "cetro de Deus, não estando obrigados a render submissão a qualquer poder na Terra". Questionar os poderes dos reis equivalia a questionar os poderes do próprio Deus: uma falta passível de severa punição.

Em 1654, Luís XIV foi coroado e sagrado numa cerimônia tradicional que colocou em evidência seu caráter divino e seu poder absoluto. No primeiro dia da cerimônia, Luís XIV foi ungido pelo arcebispo da catedral de Reims, que o abençoou com a frase: "Sejas bendito e constituído rei nesse reino que Deus the deu para reinar". Dois dias depois, o novo monarca exercitou seus dotes sagrados durante a cerimônia de cura dos escrofulosos. Três mil doentes se reuniram em fila 
diante do rei taumaturgo, que tocou cada um deles enquanto pronunciava a frase: "O Rei te toca, Deus te cura" (BURKE, 1994, p. 51, 53).

A crença nos poderes curativos dos monarcas franceses chegou a ser questionada ainda no reinado de Luís XIV. Aproveitando-se da morte repentina de uma das amantes do rei, seus adversários colocaram em dúvida os poderes curativos do monarca, afirmando que Madame de Soubise, apesar de "muito bem tocada" por Luís XIV, havia morrido de escrófulas. Os boatos parecem não ter abalado a convicção nos poderes taumatúrgicos do rei e de seu sucessor. Por volta de 1723, no reinado de Luís XV, o marquês de Argenson recolheu diversas provas de uma cura milagrosa do rei, produzindo um relatório que foi enviado à corte. Para sua surpresa, a resposta do secretário de Luís XV foi dura e definitiva: "respondeu-me secamente [...] que ninguém punha em dúvida o dom que nossos reis tinham de realizar esses prodígios" (apud $\mathrm{BLOCH}, 1998$, p. 260). Num período em que a crença nos poderes absolutistas parecia inabalável, o esforço de provar os dotes curativos dos monarcas parecia tão desnecessário quanto a tentativa de provar, através de dados materiais, a existência Daquele que os "nomeara" como seus representantes na Terra.

Os boatos a respeito da causa mortis de Madame de Soubise antecipam alguns pontos da pauta defendida pelos iluministas no século XVIII. Críticos do absolutismo, os filósofos iluministas insistiam que os monarcas franceses eram pessoas absolutamente normais às quais a ignorância atribuía poderes especiais: a faculdade de curar os escrofulosos ou governar a França como representantes de Deus. Se, no início do século XVIII, a resposta do secretário de Luís XV ao relatório do Marquês d'Argenson evidenciava quão forte era a crença nos poderes taumatúrgicos do monarca, a reação do secretário de Luís XVI aos relatos de cura de escrofulosos pelo rei sugere transformações que devem ser pensadas em conjunção com a ação dos pensadores iluministas. Em 1775, informado pelo intendente de Châlons, Rouillé d'Orfeuil, que Rémy Rivière havia sido curado depois de ser tocado por Luís XVI, o secretário Bertin respondeu ao remetente: "Recebi, senhor, a carta que me escrevestes concernente à cura do citado Rémy Rivière e coloquei-a à vista do rei; se tiverdes conhecimento de curas semelhantes, informaime" lapud BLOCH, 1998, p. 261). Numa clara demonstração de que a crença nos poderes taumatúrgicos do rei já não era tão sólida, Bertin solicitou a Rouillé d'Orfeuil que reunisse novas evidencias materiais que pudessem comprová-los, buscando demonstrar, com um discurso fundamentado na "Razão", a legitimidade de uma doutrina que só poderia ser justificada pela "Fé".

\section{Filósofos-artistas}

Analisando as especificidades do movimento filosófico, político, e artístico que recebeu o nome de lluminismo, Salinas Fortes destaca que, em termos de conteúdo das doutrinas, a geração de Voltaire, Jean-Jacques Rousseau, Diderot 
e D'Alembert pouco acrescentou ao pensamento de Bacon, Descartes e John Locke (FORTES, 1981 , p. 13, 14). As maiores diferenças entre essas duas gerações deveriam ser buscadas na postura militante que informou a ação dos pensadores do século XVIII. Movidos pelo desejo de intervir de forma mais decisiva na sociedade, os iluministas do século XVIII tinham consciência da necessidade de propagar seus ensinamentos para além dos limites das Academias e das elites cultivadas. Além dos ensaios direcionados aos especialistas, esses filósofos-artistas dedicaram-se também à literatura, teatro, música, escultura, pintura e outras manifestações artísticas que, junto com a Enciclopédia, ajudaram a propagar o ideário iluminista para os mais diversos extratos da população, atingindo, até mesmo, um público de não letrados.

Com intensa circulação nos meios intelectuais parisienses, Jacques-Louis David destacou-se na defesa do lluminismo através da pintura. Nascido numa família burguesa em 1748, David perdeu o pai aos 9 anos, quando este foi morto num duelo de pistolas. Prima distante do celebrado pintor rococó François Boucher, a mãe de David exerceu pouca influência sobre a educação do filho que, criado pelos tios, iniciou o seu aprendizado de pintura no ateliê de Joseph-Marie Vien. Em 1766, David ingressou na Academia Real de Pintura e Escultura, que funcionava no Palácio do Louvre, em Paris. Privilegiando a produção de pinturas históricas, que, por divulgar modelos de virtude e moralidade, gozavam de um status superior aos retratos e às paisagens (SCHWARCZ, 2008, p. 73-79), a formação dos alunos da Academia devia ser coroada pelo Prêmio de Roma, obtido num concurso organizado pela instituição: a partir de um tema sugerido pela direção da Academia, os alunos tinham um prazo de dez semanas para planejar e produzir telas que eram posteriormente avaliadas por seus professores. Além de acrescentar ao seu currículo um item indispensável à obtenção de encomendas mais bem remuneradas, os vencedores do Prêmio de Roma ganhavam uma bolsa que thes permitia dar continuidade aos seus estudos no Palácio Mancini, sede da Academia Francesa em Roma.

Eliminado do concurso nas provas preliminares, em 1770, David foi selecionado para a prova final do Prêmio de Roma nos anos de 1771, 1772 e 1773 sem conseguir, no entanto, vencer o certame. Esses insucessos reforçaram as prevenções do pintor contra a Academia que, em sua opinião, objetivava formar artistas obedientes e submissos: mais do que o talento e a criatividade, o Prêmio de Roma recompensava a capacidade dos alunos em ajustar suas obras ao gosto dos mestres, coroando um processo que reproduzia a irracionalidade e o autoritarismo do "Antigo Regime". Sem alternativa senão cumprir os requisitos imprescindíveis à evolução de sua carreira, David continuou participando do concurso, vencendo-o, em 1774, com a tela Erasistrato descobre que a causa do mal de Antiocho é seu amor por Estratonice (Figura 1).

No mesmo ano em que David conquistou o Prêmio de Roma, Luís XVI assumiu o trono francês. Embora não nutrisse maior paixão pelas artes, o novo monarca thes dedicou atenção, incentivando a produção de pinturas históricas que 
Figura 1 - Erasistrato descobre que a causa do mal de Antiocho é seu amor por Estratonice. Jacques-Louis David, 1774. Óleo sobre tela, $120 \times 165$ $\mathrm{cm}$. École Nationale Supérieure des Beaux-Arts, Paris, França.

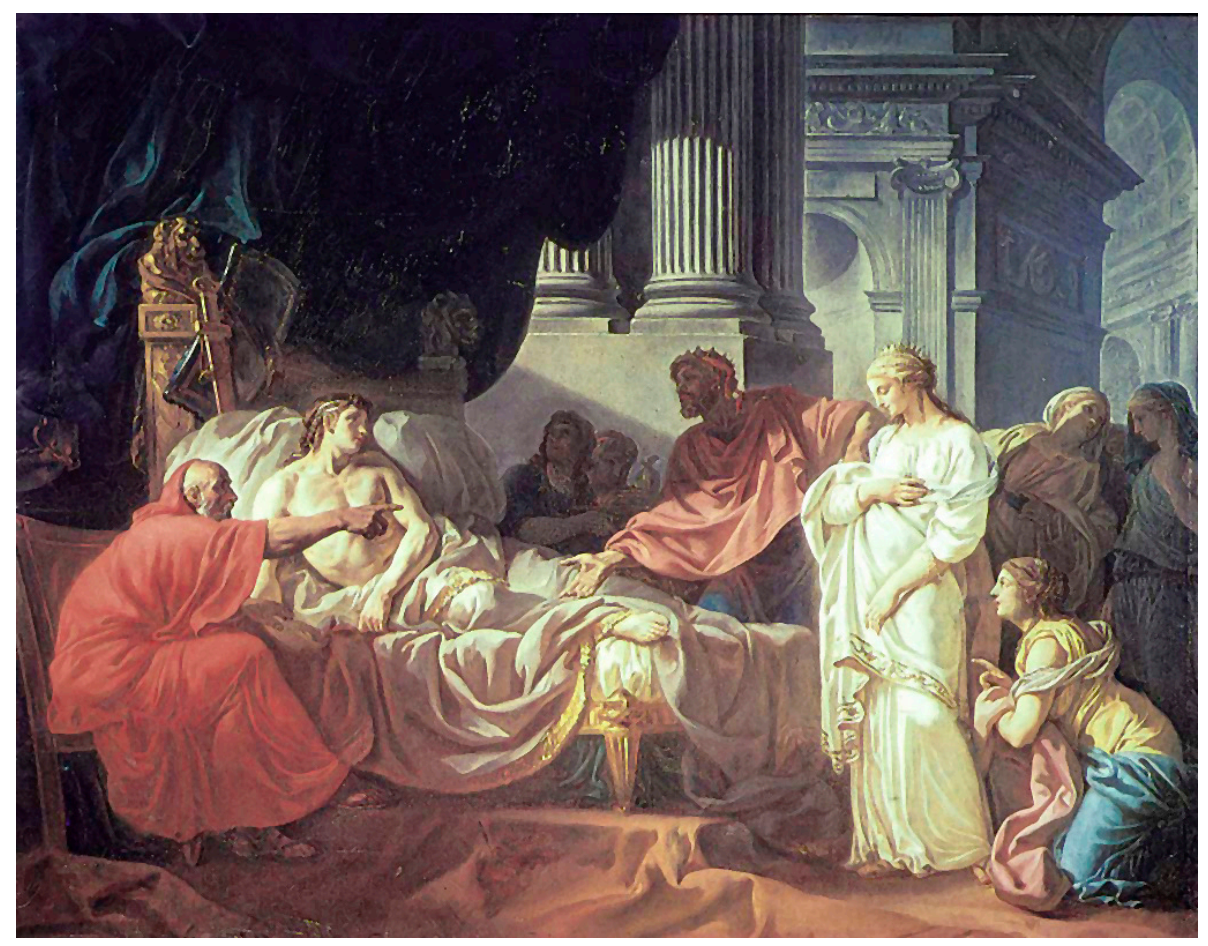

poderiam contribuir para a consolidação da identidade nacional. Buscando atingir tais objetivos, Luís XVI nomeou Charles de Flahaut de la Billaderie, o conde de D'Angiviller, para o posto de Directeur des Bâtiments du Roi.

Em outubro de 1775 David partiu para Roma, passando antes por curtas temporadas de estudos em Bolonha e Florença. As descobertas arqueológicas de Herculano (1738) e de Pompeia (1748) e a defesa da cópia de obras clássicas propugnada por teóricos como Johan Joachim Winckelmann haviam contribuído para aumentar o interesse dos artistas europeus pela Itália. Em Roma, David dedicou-se com grande afinco ao estudo de obras clássicas sob o olhar atento de Joseph Marie Vien: o antigo mestre do pintor que fora recentemente nomeado como diretor da filial da Academia Francesa.

Os primeiros trabalhos realizados por David em Roma, Os funerais de Patroclo (1778), Patroclo (1778?) e Heitor (1778), são indicativos da atração do pintor pelos temas clássicos dos quais ele teve de momentaneamente se afastar para atender aos desejos de seus primeiros clientes. $\bigcirc$ sucesso alcançado por São Roque intercedendo à Virgem pelos doentes de peste (1780), inicialmente destinado a decorar o lazareto de Marselha, atraiu as atenções do conde de Potocki, que encomendou um retrato ao jovem pintor: Retrato do conde Potocki (1780 - Figura 2). Inspirando-se em retratos equestres de reis e soberanos que buscavam associar suas habilidades no manejo de cavalos a seus talentos na condução de povos e nações, David atendeu às expectativas do nobre polonês com um retrato de grandes dimensões: $304 \mathrm{~cm} \times 218 \mathrm{~cm}$. Um detalhe da tela, 
no entanto, parece revelar aos olhos mais atentos a perspectiva do pintor em relação ao conde Potocki: sua assinatura estrategicamente colocada na coleira do cachorro, que rosna para o garboso cavaleiro.

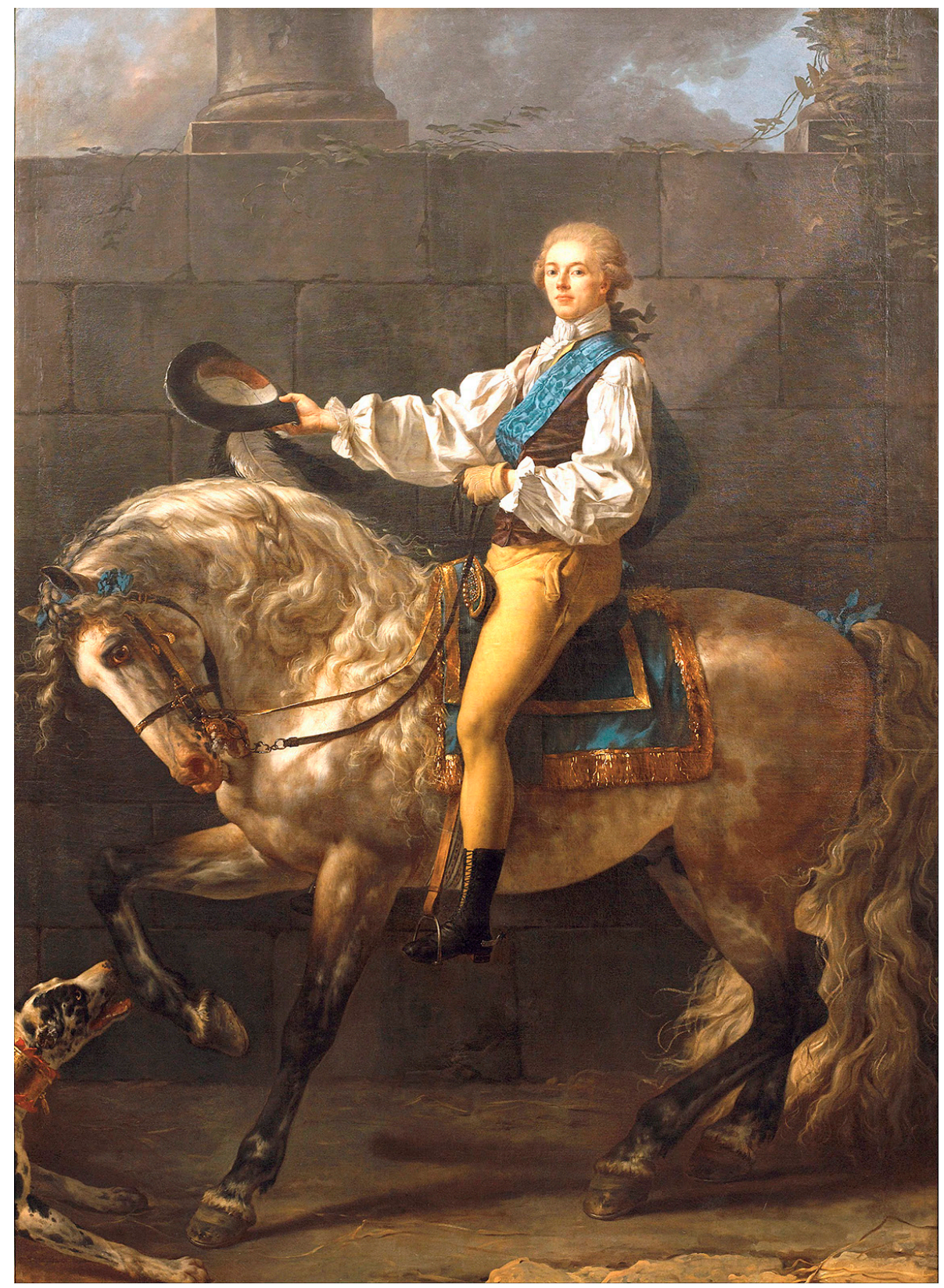

Figura 2 - Retrato do conde Potocki. Jacques-Louis David, 1780. Óleo sobre tela, $304 \times 218 \mathrm{~cm}$. Museu do Palácio Real de João III, Varsóvia, Polônia.

De acordo com Simon Lee, o "sucesso de São Roque e Potocki [...] convenceram o jovem e ambicioso artista [de] que era chegado o tempo de retornar para casa, levando-o a recusar a prorrogação de sua bolsa por um sexto ano" (LEE, 1999, p. 54). Em julho de 1780, David iniciou sua viagem 
de retorno à França, requerendo sua admissão na Academia Real de Pintura e Escultura tão logo chegou a Paris. $O$ ingresso na Academia Real de Pintura e Escultura era uma etapa importante na carreira dos artistas franceses que, como membros da Instituição, credenciavam-se a receber encomendas reais e expor seus trabalhos no Salão de Paris: a mais prestigiada mostra de arte francesa, realizada a cada dois anos no Palácio do Louvre. Numa primeira etapa do processo, o artista submetia seus trabalhos à avaliação dos membros da Academia que, em caso de aprovação, admitiam-no como "agregado" (agrée) da instituição. Numa segunda etapa, o artista produzia uma obra sobre um tema definido pelos diretores que, uma vez avaliada e aprovada, garantia a seu autor o tífulo de "membro" (reçu) da Academia.

Obedecendo ao rito-padrão, David submeteu seus trabalhos aos dirigentes da Academia que, sob a justificativa de que o pintor só apresentara obras realizadas fora da França, recusou-lhe aprovação. $O$ parecer do Primeiro Pintor do Rei, Jean-Baptiste Pierre, não conseguia encobrir os motivos determinantes da recusa: o desejo de punir um dos mais severos críticos da instituição. Uma vez notificado, David deu início à produção de seu quadro "parisiense", escolhendo com extremo cuidado o tema da obra que lhe permitiria adentrar os portões da Academia: Deem uma esmola a Belizário (1781 - Figura 3).

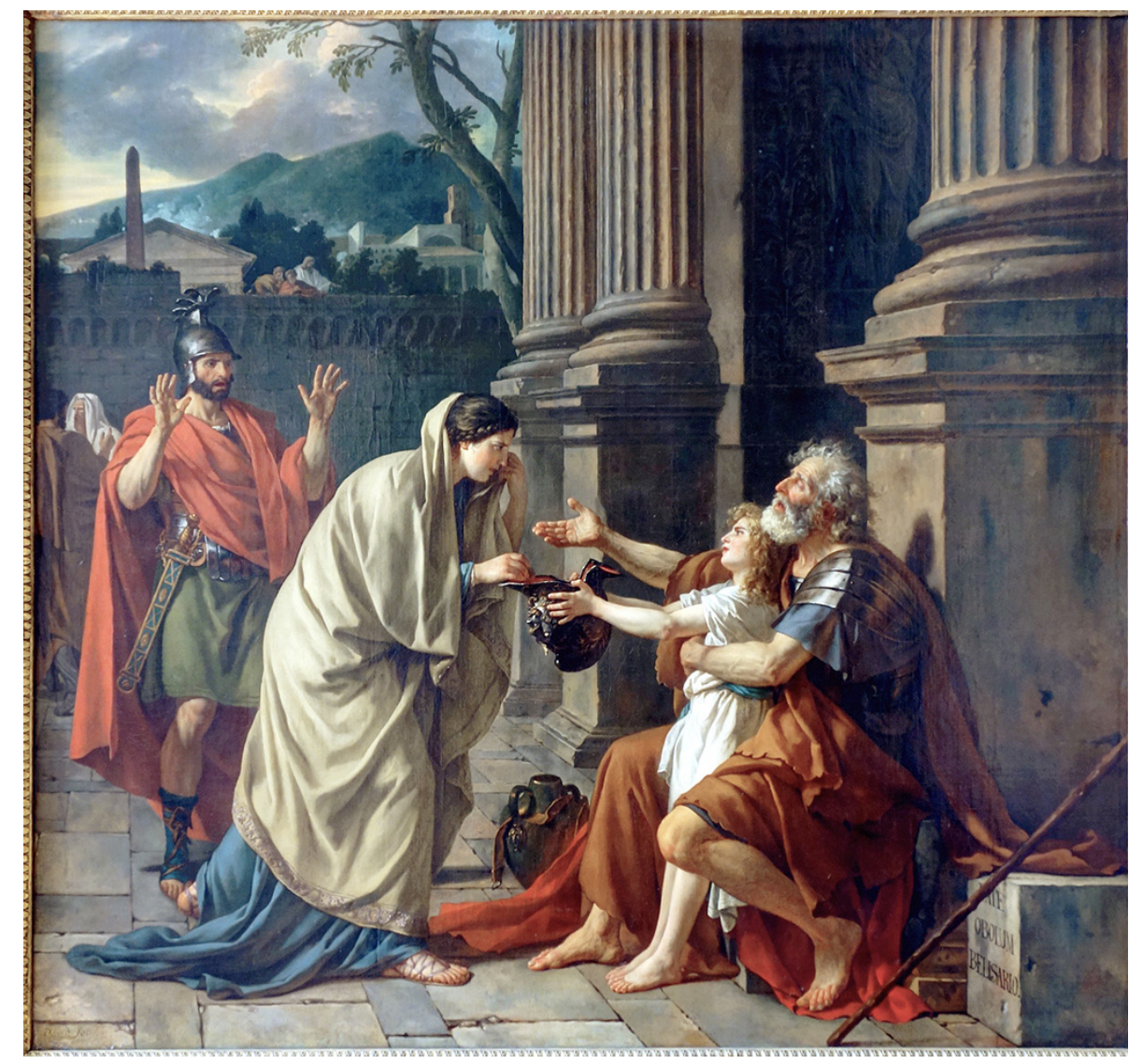

Figura 3 - Deem uma esmola a Belizário. Jacques-Louis David, 1781. Óleo sobre tela, $312 \times 288$ $\mathrm{cm}$. Palais Beaux Arts Lille, Lille, França. 
2. Esse reconhecimento foi celebrado num quadro de J. B. C. Robin, Lally-Tollendal descobrindo o busto do seu pai. O filho do militar desvela o busto do pai enquanto segura uma carta que, endereçada ao rei, expõe seu conteúdo aos observadores da tela: "Mon père n'est pas coupable". Cf. Simon Lee (1999, p. 5966) e Robert L. Herbert (1973, p. 59-60).
Talentoso general, Belizário havia se tornado uma figura muito popular no Império Bizantino, competindo em prestígio com o imperador Justiniano I. Ao combater os ostrogodos, seus talentos foram reconhecidos pelos adversários, que the propuseram uma aliança: os "bárbaros" reconheceriam Belizário como seu soberano se este concordasse em liderá-los na formação de um novo Império. O general simulou aceitar o acordo, obteve a "rendição" dos ostrogodos, mas recusou a coroa que the foi oferecida, uma vez que sempre permanecera fiel a Justiniano. O novo êxito de Belizário, no entanto, provocou a ira do imperador que, eclipsado pelo prestígio crescente do general, acusou-o de traição. Ao retornar a Bizâncio, Belizário foi encarcerado e teve seus bens confiscados por ordem do soberano.

Datado do século VI, o drama do general Belizário ganhara atualidade com o caso do marquês Thomas Arthur de Lally: militar escolhido como bode expiatório pela Coroa francesa na ocasião da derrota para os ingleses, em 1761, na Batalha de Pondicherry. Injustamente acusado de covardia e traição, Thomas Arthur de Lally foi preso e executado em 1766. O affaire mobilizou os iluministas, que o denunciaram como um exemplo dos malefícios do regime absolutista. Em 1767, o filósofo e escritor Jean-François Marmontel se uniu a esse coro com Belizário: romance que, entrelaçando história e ficção, "exagera" as penas impostas ao general bizantino, afirmando que o mesmo teria sido cegado por ordem de Justiniano. $\bigcirc$ tom crítico do romance não escapou aos censores que, cientes das associações que poderiam ser estabelecidas entre Belizário e Thomas Arthur de Lally / Justiniano e Luís $X V$, tentaram impedir sua divulgação. Liderado pelo filho do militar e por Voltaire, o movimento pela reabilitação do marquês de Lally entrelaçou-se à defesa do romance de Marmontel que, uma vez liberado, alcançou grande sucesso. A campanha alcançou nova vitória em 1778 quando, pressionado pela opinião pública, Luís XVI reconheceu a injustiça cometida contra o militar. ${ }^{2}$

Dialogando com a peça de Jean-François Marmontel, Deem uma esmola a Belizário apresenta o general como um cego que, auxiliado por um garoto que the serve de guia, surpreende um antigo companheiro de armas ao pedir esmolas numa das entradas de Bizâncio. Numa referência às dificuldades criadas por Jean Baptiste Pierre para seu ingresso na Academia, David assinou a obra com a inscrição latina "L. David faciebat anno 1781 Lutetiae": numa tradução aproximada, "L. David fez esse quadro, no ano de 1781, em Lutetiae", nome utilizado pelos romanos para se referir à antiga Paris. Sentado próximo a um dos arcos de Bizâncio, fora dos limites da cidade, Belizário expunha não só o drama do general, mas também o do pintor, que não conseguira passar pelos portões da Academia. De ponta-cabeça, o elmo de Belizário denunciava o absurdo de um mundo em que impérios, reinos e academias de arte eram administrados por tiranos movidos por seus mais espúrios interesses pessoais. Com sua cegueira, o Belizário retratado expunha as trevas que deveriam ser extirpadas pela ação dos intelectuais e artistas iluministas.

Em 24 de agosto de 1781, Jacques-Louis David apresentou Deem uma esmola a Belizário e seus quadros "romanos" à Academia: ato que 
contrariava a norma que proibia a admissão de novos membros às vésperas da abertura do Salão de Paris. ${ }^{3}$ Argumentando desconhecer a norma "recémcriada" e manifestando o desejo de "instruir-se" submetendo suas obras à avaliação de seus "mestres", David conseguiu o apoio de membros da instituição que, contrariando Jean-Baptiste Pierre, avalizaram sua admissão como um "agregado" (agrée) da Academia. A surpreendente "aparição" de Deem uma esmola a Belizário no Salão de 1781, dias após a abertura da exposição, contribuiu para aumentar o interesse sobre o quadro que se tornou objeto de debates apaixonados. Em carta à mãe, o pintor regozijou-se de seu sucesso, destacando como a Academia o havia recebido "de maneira pouco comum" (David épistolier: À sa mère apud SAHUT; MICHEL, 1988, p. 138 139): com o seu quadro sobre o general-mendigo, Jacques-Louis David não havia, como era regra, atravessado os portões da Academia de joelhos, tendo a chance de encarar seus dirigentes de pé.

\section{juramento dos Horácios}

A admissão de Jacques-Louis David como "agregado" da Academia abriu novas perspectivas para o pintor, que se casou com Marguerite-Charlotte Pécoul e começou a receber alunos pagantes em seu estúdio. Em 1782, David recebeu sua primeira encomenda da Direction des Bâtiments du Roi: um quadro sobre o tema $\bigcirc$ velho Horácio defendendo seu filho do assassinato da irmã Camila. Preocupado em finalizar Andrômaca pranteando Heitor (1783 - Figura 4), que the garantiu, em 25 de agosto de 1783, o título de "membro" (reçu) da Academia, David protelou a produção da encomenda real. Episódio da llíada, Andrômaca pranteando Heitor guarda grandes semelhanças com um episódio da vida do pintor que, como o garoto Astyanax, também havia consolado sua mãe quando o pai morrera num duelo. Uma vez assegurado seu novo status na Academia, David retomou a encomenda da Direction des Bâtiments du Roi, decidindo, por conta própria, mudar-lhe o tema. A "cena" de $\bigcirc$ velho Horácio defendendo seu filho do assassinato da irmã Camila foi substituída por outro episódio relacionado ao mesmo "enredo": O juramento dos Horácios (1784/85 - Figura 5).

Com o recrudescimento dos conflitos entre Roma e Alba em 669 a.C., as cidades decidem resolver suas diferenças num combate em que seriam representadas pelos seus três melhores guerreiros. A escolha dos três irmãos Horácios para representar Roma e dos três irmãos Curiáceos para representar Alba gerou desespero às mulheres, para quem o combate reservava um resultado necessariamente trágico: Sabina, esposa de um dos Horácios, era irmã dos Curiáceos; e Camila, irmã dos Horácios, era noiva de um Curiáceo. Terminado o combate, o único dos Horácios que sobrevivera à peleja retornou a sua casa para trazer a boa-nova: Roma havia vencido. Informada do
3. A proibição estava relacionada à necessidade de inclusão dos trabalhos dos novos "agregados" na mostra: como a distância que separava as telas era mínima, a liberação de espaço para a inserção de novos quadros exigia a reorganização de toda a exposição. 
resultado, Camila se revolta, acusa o irmão de assassinato, lança uma praga contra Roma e é morta pela mesma espada que havia derrubado os Curiáceos: se a acusação de assassinato não merecia maior atenção, as ofensas contra Roma não podiam ser perdoadas.

A encomenda da Direction des Bâtiments du Roi a David estava relacionada ao enredo narrado acima: o momento em que o velho Horácio, no papel de advogado, assume a defesa do filho no julgamento em que esse era acusado do assassinato da irmã. No entanto, como já foi dito, David decidiu pintar uma "cena" que, relacionada ao mesmo drama, não havia sido descrita por nenhuma outra fonte anterior: o momento em que os Horácios comprometem-se, diante do pai, a defender Roma.

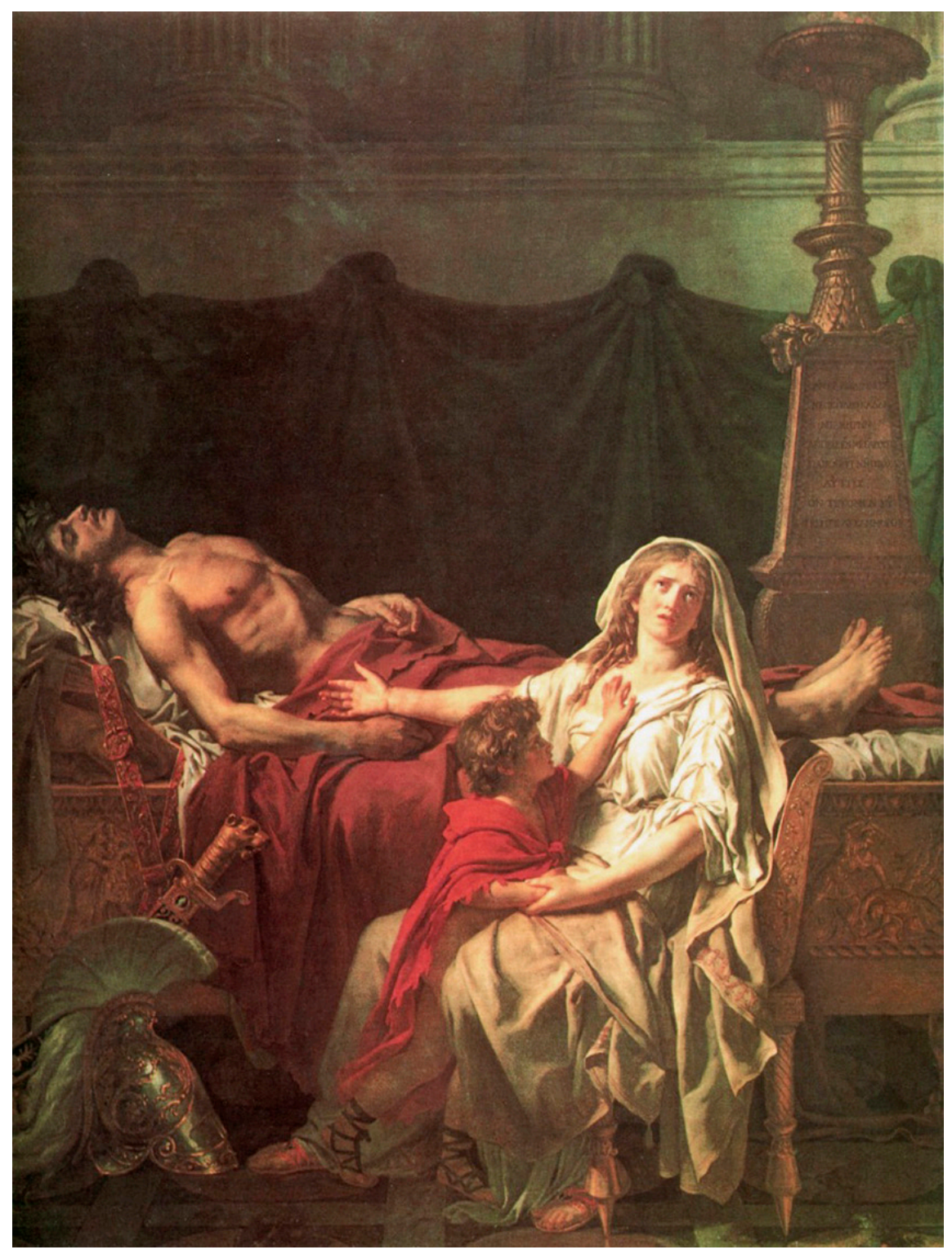

Figura 4 - Andrômaca pranteando Heitor. Jacques-Louis David, 1783. Óleo sobre tela, $275 \times 203 \mathrm{~cm}$. Pushkin Museum, Moscou, Rússia. 


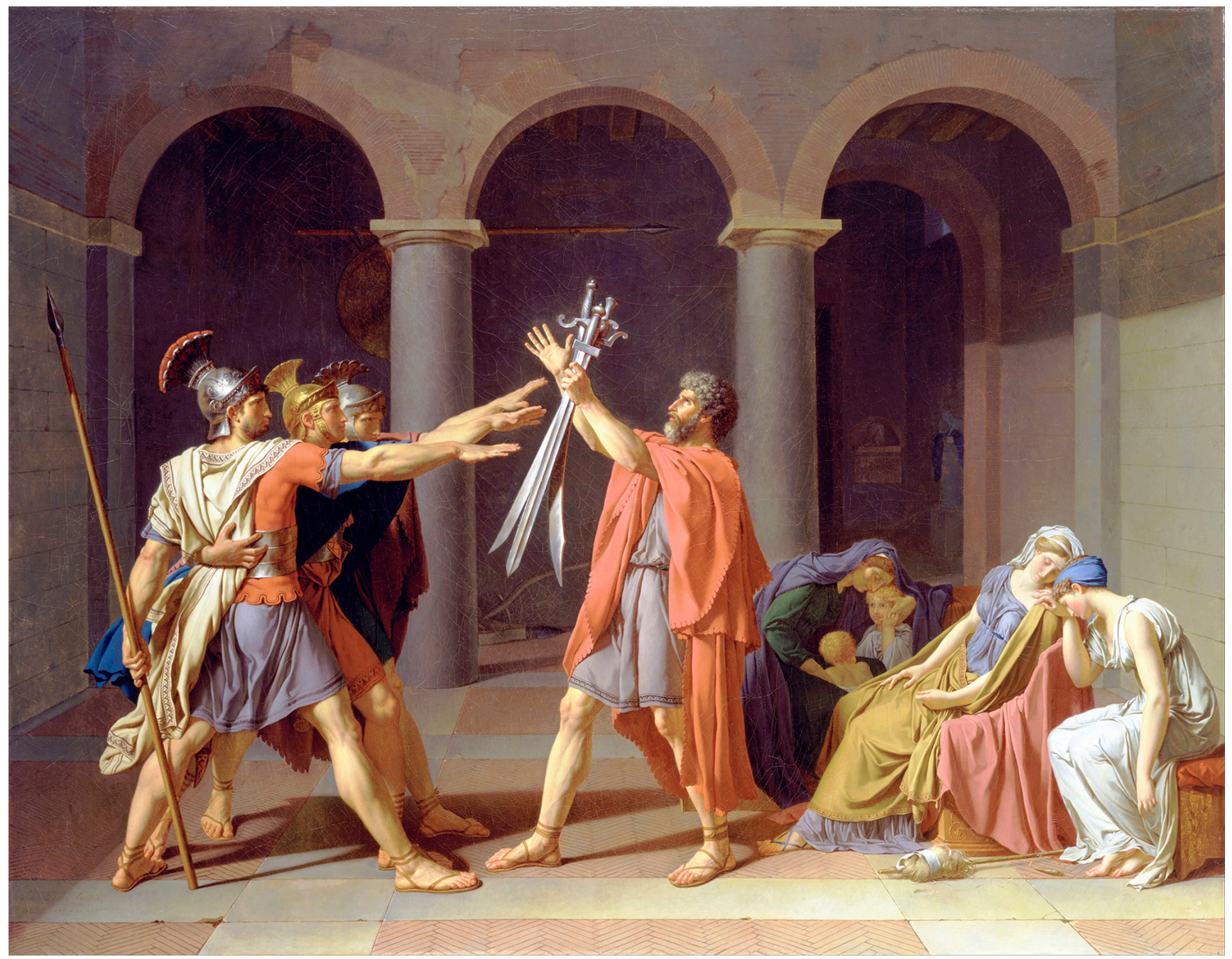

Figura 5 - O juramento dos Horácios. Jacques-Louis David, 1784 / 1785. Óleo sobre tela, $330 \times 425$ cm. Louvre, Paris, França.

O juramento dos Horácios se divide em três espaços bem definidos: - grupo dos irmãos que estendem seus braços no momento do juramento (esquerda), o pai que segura espadas e incita os filhos para o combate (centro) e o grupo das mulheres que se desesperam diante da tragédia (direita). Analisando o quadro, Jean Starobinsky (1988, p. 72, 73) destaca como, no momento do juramento, os personagens masculinos recusam uma troca de olhares, concentrando sua atenção no punho das espadas que, representando Roma, interpõem-se entre o pai e os filhos: uma alusão às virtudes dos bons cidadãos que colocavam os interesses da pátria à frente dos individuais. Governados pela razão, os jovens não hesitam em arriscar suas vidas, e o pai a de seus filhos, em benefício de Roma, ao contrário das mulheres que, dominadas pela emoção, deixam-se levar pelo desespero. Camila, de vestido 
4. "[...] o artista grego em todas as suas figuras traçou o contorno como se o fizesse com a ponta de um cabelo [...]. Mesmo sob a vestimenta das figuras gregas reina um contorno perfeito que é o objetivo primordial do artista, mostrando, mesmo através do mármore, a bela estrutura do corpo sob uma vestimenta de Cós". Cf. Johan Joachim Winckelmann (1975, p. 49-50).

5. É esse traço característico do neoclassicismo que nos autoriza empreender uma análise do inacabado $O j u$ ramento do jogo da pela a partir do projeto/desenho de Jacques-Louis David. azul, e Sabina, de vestido branco, destacam-se à direita do quadro, iluminadas pela luz que se derrama sobre o pai e os irmãos. Colocada estrategicamente entre o grupo das mulheres e o pai, a mãe dos Horácios, encoberta pelas sombras do grupo masculino, lamenta a sorte da família, ao mesmo tempo que tenta confortar e proteger dois garotos. Parecendo recusar sua "posição", um dos meninos puxa a mão da mãe que, cobrindo seus olhos, tentava evitar que ele presenciasse o juramento: instintivamente, o garoto parece ter consciência de que, num futuro próximo, também ele deveria juntar-se ao grupo dos homens, oferecendo sua vida em defesa da pátria.

Considerado um dos exemplos mais bem-acabados do neoclassicismo, O juramento dos Horácios expõe características que nos permitem apontar algumas especificidades desse estilo. Comparadas às do rococó ou do romantismo, as obras neoclássicas caracterizam-se por uma "sobriedade" que se expressa na escolha dos temas e também na forma como esses são abordados. Leitor de Winckelmann, Jacques-Louis David concordava com o autor alemão quando este afirmava que "o único meio de nos tornarmos grandes e, se possível, inimitáveis, é imitar os antigos" (WINCKELMANN, 1975, p. 39-40). Emulando os artistas gregos a partir das indicações de Winckelmann, ${ }^{4}$ Jacques-Lovis David constrói seus personagens com contornos bem demarcados: traço característico do neoclassicismo que privilegiava o "desenho" a "cor". Como destacam Nigel Blake e Francis Frascina (1998), os artistas neoclássicos "viam a si mesmos como intelectuais": um status que estava diretamente relacionado à "sua capacidade de projetar ou compor um quadro, de dispor ou ordenar elementos de uma obra de maneira a deixar clara a sua importância relativa e destacar os significados de uma obra". Nesses termos, "o desenho era considerado uma tarefa menos manual do que a pintura", uma vez que o projeto ou composição do quadro se definia, primordialmente, no momento em que o artista "desenhava", em papel, os esboços que seriam posteriormente "reproduzidos" e "coloridos" em tela. Traduzindo, no plano estilístico, a oposição entre razão masculina $\times$ emoção feminina tematizada em $\bigcirc$ juramento dos Horácios, os artistas neoclássicos consideravam que "a cor servia para pouca coisa mais que 'preencher' um desenho e tinha escasso valor por conta própria", estando associada "à 'emoção' e à 'sensibilidade', ambas consideradas 'femininas' e destituídas de interesse teórico" (BLAKE; FRASCINA, 1998, p. 60-61).5

Depois de realizar o "projeto" de $\bigcirc$ juramento dos Horácios em Paris, David decidiv executá-lo em Roma, dirigindo-se para a ltália em outubro de 1784. Terminada em fins de julho de 1785, a tela foi apresentada com grande sucesso no estúdio romano do pintor, sendo depois exibida no Salão de Paris. $\mathrm{Na}$ perspectiva de críticos de época, O juramento dos Horácios denunciava a hipocrisia da monarquia e da nobreza francesa ao exaltar, num jogo de contrastes, a virtude e correção dos Horácios: colocando os interesses do Estado à frente dos seus pessoais, os romanos eram a antítese dos aristocratas, que não conferiam importância à coisa pública. 
Em meio à polêmica gerada pelo quadro, David lançou sua candidatura ao cargo de diretor da Academia Francesa de Roma, que ficaria vago no início de 1787. As circunstâncias que cercaram a produção e a exibição de $O$ juramento dos Horácios foram decisivas para que o pintor não conseguisse o cargo. O tom crítico da obra, a mudança do tema inicial sem prévia autorização da Direction des Batiments du Roi e a ampliação das dimensões da tela ${ }^{6}$ enfureceram D'Angiviller e Jean-Baptiste Pierre, que preteriram Jacques-Louis David em favor de François-Guillaume Ménageot.

\section{A morte de Sócrates}

O roteiro de $\bigcirc$ juramento dos Horácios repetiu-se, com algumas mudanças, quando David recebeu, em 1787, sua segunda encomenda da Direction des Bâtiments du Roi: uma tela sobre o tema Coriolano retornando a Roma. Num novo desafio a D'Angiviller e Jean-Baptiste Pierre, Jacques-Louis David protelou a execução da encomenda, dedicando-se à produção de uma obra que the permitiria discutir, dentre outras questões, seus conflitos com os dirigentes da Academia: A morte de Sócrates (1787 - Figura 6). Encomendada por Charles Michael Trudaine, ${ }^{7}$ A morte de Sócrates se debruça sobre a "execução" do pensador, condenado pela acusação de não reconhecer os deuses e corromper os jovens. David retrata o momento em que Sócrates, dando mais importância ao magistério que à própria morte, dirige a mão para a taça de cicuta sem desviar os olhos dos discípulos que continuam a ouvi-lo: dois deles haviam sido designados para acompanhar Xantipe, esposa do filósofo, que, à esquerda do quadro, é retirada de sala. Preocupado em imprimir "significados" que aumentassem o impacto da obra aos olhos de seus contemporâneos, David desviou-se de Fédon: texto em que Platão, a partir do diálogo entre Fédon e Equécrates, discorre sobre os últimos momentos do mestre. Doente, Platão não pudera acompanhar a morte de Sócrates, mas foi inserido no quadro: o idoso com vestes brancas, sentado num banco ao pé da cama do sentenciado. Se incluirmos Xantipe e os dois discípulos que a acompanham, contaremos doze participantes nessa "Última Ceia" em que o vinho fora substituído pela cicuta. Sugerida pelo quadro de David, a associação entre Sócrates e Jesus Cristo não era nova, tendo sido estabelecida pelos próprios cristãos que, buscando referências ao Salvador, reinterpretaram - Antigo Testamento e os clássicos greco-romanos tomando Sócrates como "um precursor de Cristo":

$\bigcirc$ Logos divino, destinado a aparecer em Jesus, tinha sido ativo em Sócrates, que denunciou o politeísmo e a adoração dos gregos ao diabo. Como pessoa que "viveu razoavelmente, isto é, de acordo com o Logos", ele era "um cristão antes de Cristo" e, como Cristo, foi morto pelos inimigos da razão e do Logos. (PELIKAN, 2000, p. 43)
6. O "contrato" previa uma tela de $3 \mathrm{~m} \times 3 \mathrm{~m}$, mas David pintou-a num formato de $3,30 \mathrm{~m} \times 4,25 \mathrm{~m}$. Numa repetição do que ocorrera no Salão de 1781, a necessidade de se encontrar espaço para a obra exigiu a remontagem de toda exposição.

7. Junto com o irmão Charles Louis, Charles Michael Trudaine liderava a Societé Trudaine, integrada por "nobres liberais, escritores iluministas e intelectuais". Ver Simon Lee (1999, p 101-102). 


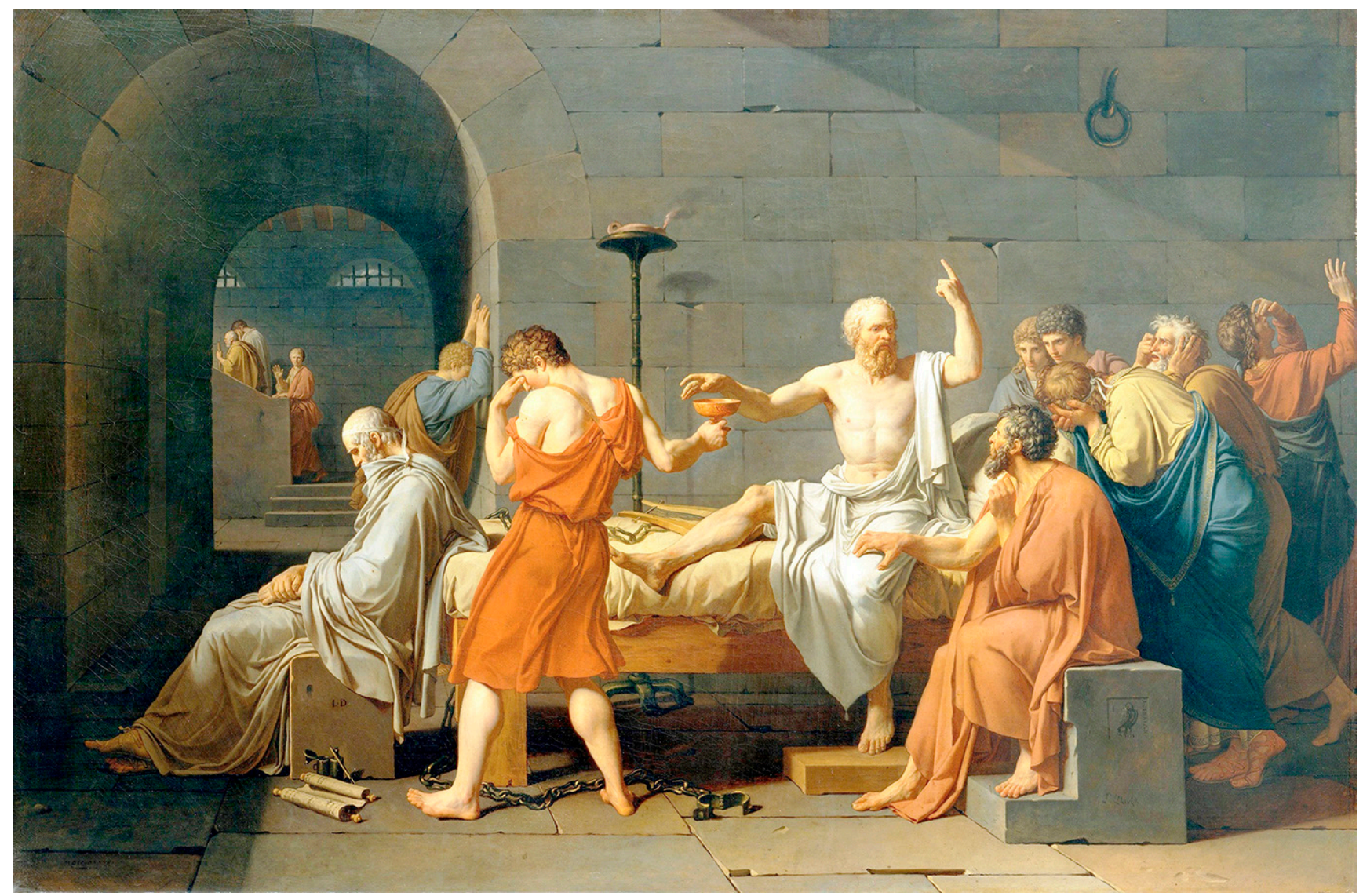

Figura 6 - A morte de Sócrates. Jacques-Louis David, 1787. Óleo sobre tela, $129 \times 196$ cm. Metropolitan Museum, Nova lorque, Estados Unidos.

Abarcando significados traduzidos como "palavra, discurso, menção, declaração, afirmação, dito, provérbio, resolução, ordem, proclamação, doutrina, oráculo, verbo, matéria, questão, discurso, palavra, colóquio, narrativa, oração, discurso, totalidade, significado, argumentação, razão, pensamento, causa, fundamento, justificação, causa" (RUSCONI, 2005), o termo Logos é associado à "Palavra de Deus" em João. Recuperando uma ideia já presente no Gênesis, João destaca como, através de Cristo, "o Verbo se fez carne, e habitou entre nós, e vimos a sua glória, como a glória do unigênito do Pai, cheio de graça e de verdade" (João 1). O trecho de João nos ajuda a compreender um detalhe importante de imagens que, a partir de Bizâncio, tornaram-se muito populares na arte cristã ocidental. Do grego "a que nos mostra ○ Caminho", as Hodegétrias representam a Virgem e o Filho que carrega, em sua mão esquerda, um rolo de pergaminho: "um símbolo do Logos divino ou Verbo" (BELTING, 1998, p. 391).

Portador do Logos, Sócrates era um "precursor de Cristo", mas não compartilhava da natureza divina que ligava Esse último ao Pai. Sócrates era 
humano, como o outro elemento do quadro de David que poderia ser associado ao Logos: o rolo de pergaminho que, importante notar, é acompanhado pela pena e pelo tinteiro. Se no Gênesis e em João a criação do Universo e a encarnação de Jesus Cristo podem ser entendidas como manifestações do Verbo Divino ("Disse Deus..."), em A morte de Sócrates a "ativação" do Logos não pode ser desvinculada da ação humana: o mestre que palestra e o discípulo que, com a pena e o tinteiro, encarrega-se de registrar suas palavras. Embora - Hades fosse percebido pelos gregos como um "mundo subterrâneo", Sócrates aponta com o indicador de sua mão esquerda para o céu: fazendo uso da razão e do Logos ele conquistaria, com ajuda de Platão, a imortalidade reservada aos deuses olímpicos e celestes.

Os amores de Paris e Helena

Em 1788, para surpresa dos meios artísticos franceses e do próprio pintor, David recebeu uma encomenda do conde D'Artois, personagem que parecia encarnar todas as críticas dos intelectuais iluministas contra a nobreza. Irmão de Luís XVI, D'Artois dedicara sua juventude a gastar o dinheiro que the era garantido pela Coroa, demonstrando incompetência nos raros momentos em que, como militar, fora convocado a servir à França. Por volta de 1785, depois de assumir uma relação estável com a viscondessa de Polastron, o conde D'Artois passou a nutrir um interesse maior pelos assuntos políticos, tornando-se um defensor intransigente dos privilégios da nobreza.

Encarando a encomenda como um desafio, David escolheu Os amores de Paris e Helena (1788 - Figura 7) como o tema que Ihe permitiria tecer comentários sobre seus novos clientes. Filho de Hécuba e Príamo, Paris tivera seu papel na destruição de Troia, o que fora previsto pela mãe que, nos últimos dias de sua gravidez, sonhara que paria uma tocha que incendiava a cidade. Ciente do perigo, Príamo ordenou que seu filho fosse morto logo depois do nascimento: ordem que não foi cumprida por Hécuba, que o entregou a Agislau. Criado como um simples pastor, Paris foi nomeado como juiz num "concurso de beleza" entre Hera, Atena e Afrodite, concedendo seu voto à última, que prometera auxiliá-lo na conquista da mais bela mulher do mundo: a jovem Helena, esposa de Menelau, rei de Esparta. Participando de jogos fúnebres realizados em sua memória, Paris foi reconhecido pelos pais e acolhido no palácio real. Em visita a Esparta, com a ajuda de Afrodite, Paris seduziu Helena, levando-a para Troia: montara-se o cenário do conflito que terminaria com a destruição do reino de Príamo.

Encarado na França do século XVIII como uma espécie de anti-herói da llíada, Paris parecia ser o personagem ideal para a obra em que David, recuperando temas que já trabalhara em Deem uma esmola a Belizário e $O$ Juramento dos Horácios, denunciaria o espírito dissoluto do conde D'Artois e da viscondessa de Polastron. Em Os amores de Paris e Helena, o casal troca carícias 
sem demonstrar nenhuma preocupação com as consequências trágicas de seu romance. Responsável direto pela guerra, Paris prefere dedilhar as cordas da harpa a retesar a do arco com que, seguindo o exemplo do irmão Heitor, deveria defender Troia. Pendurados numa estátua de Afrodite, deusa do amor, o arco e a aljava realçam o descaso de Paris para com os interesses da nação, espelhando o comportamento da aristocracia francesa que, na defesa de seus interesses, não hesitava questionar os poderes absolutistas de Luís XVI.

Em 1786, diante do estado falimentar do Tesouro francês, Luís XVI propôs uma reforma fiscal que previa a taxação do Primeiro e do Segundo Estados, até então isentos do pagamento de impostos. Submetido a uma Assembleia de Notáveis e ao Parlamento de Paris, o projeto foi rechaçado pela nobreza, que se recusou a abrir mão de suas isenções. Os resultados do conflito são conhecidos: em 5 de julho de 1788, Luís XVI vergou-se às exigências da nobreza, convocando os Estados Gerais. Adensava-se a crise política que, entrelaçada à econômica, conduziria a França para a Revolução.

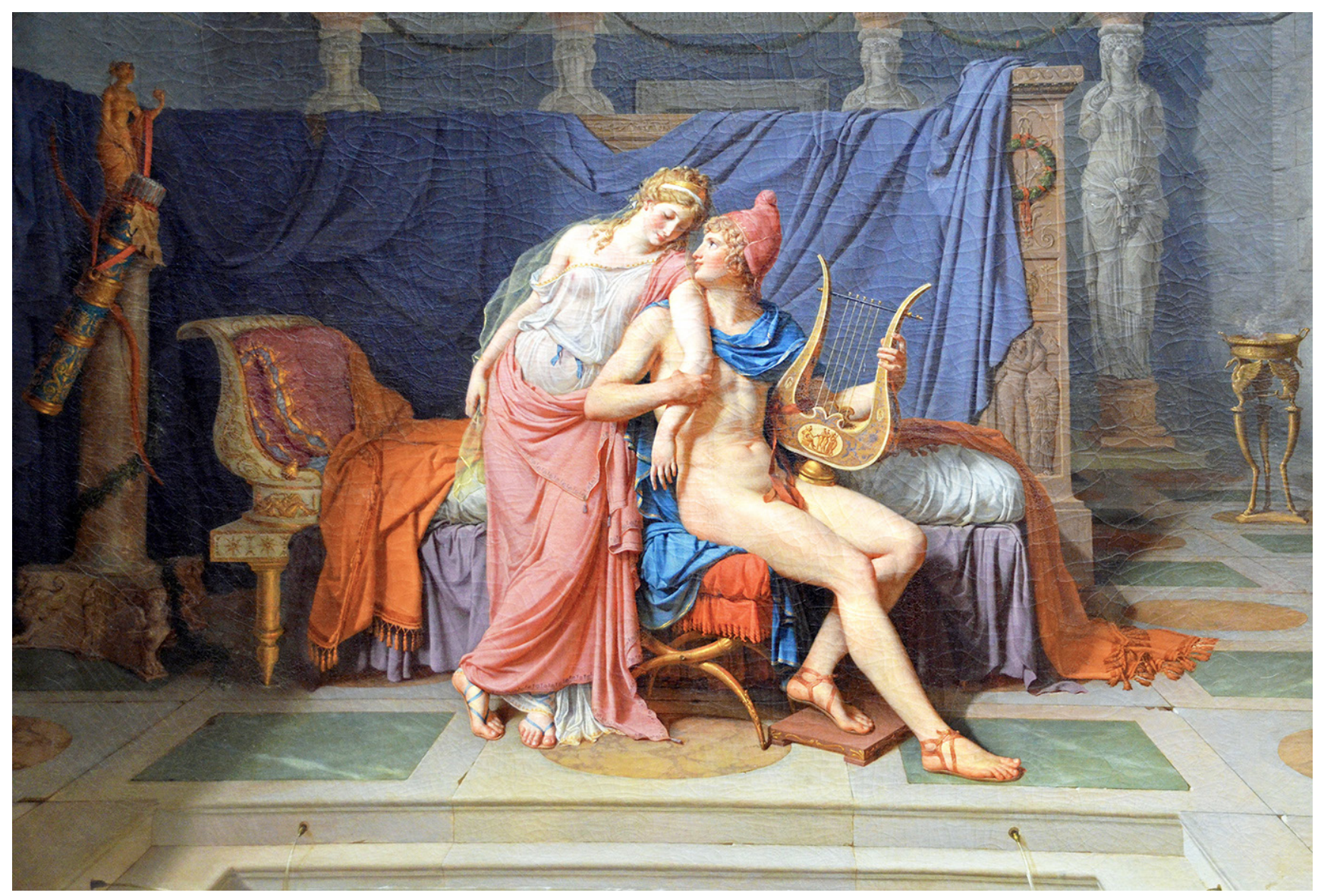

Figura 7 - Os amores de Paris e Helena. Jacques-Louis David, 1788. Óleo sobre tela, $146 \times 181 \mathrm{~cm}$. Louvre, Paris, França. 
Incentivado pelos eventos de 1789, Jacques-Louis David lançou um novo desafio a D'Angiviller e Jean-Baptiste Pierre ao retomar a encomenda que the fora feita pela Direction des Bâtiments du Roi. Repetindo a estratégia de $\bigcirc$ juramento dos Horácios, o pintor desprezou o tema que Ihe fora designado, Coriolano retornando a Roma, para debruçar-se sobre um assunto mais afinado com o momento histórico: Brutus. Na Roma da segunda metade do século VI a.C., Tarquínio e Túlia, filha do rei Sérvio Túlio, assassinam seus respectivos cônjuges para apressar sua união. Sedento de poder, Tarquínio mata também o sogro, tornando-se rei de Roma. Quando membros da aristocracia the manifestam oposição, Tarquínio os reprime com violência, promovendo uma série de assassinatos: toda a família de Lucius Junius Brutus é eliminada, mas ele consegue escapar ao massacre, simulando padecer de grave distúrbio mental.

Filho de Tarquínio e Túlia, Sextus enamora-se de Lucrécia que, fiel a Collatinus, resiste às investidas do príncipe. Inconformado, Sextus violenta Lucrécia que, além do trauma de ter sido violentada, passa a ser consumida pelo remorso de ter, ainda que involuntariamente, "traído" o marido. Desesperada, Lucrécia procura Collatinus em praça pública, "confessa" como havia sido forçada a manter relações sexuais com Sextus e, buscando expiar-se da "traição", finca um punhal em seu coração. Indignado com a cena, Lucius Junius Brutus abandona seu papel de doente mental, arranca o punhal de Lucrécia e, apoiado por Collatinus e outros cidadãos, inicia uma rebelião contra os Tarquínios. Com a expulsão dos tiranos em 510 a.C., os romanos fundam uma República, elegendo Brutus como seu "primeiro cônsul". Tempos depois, Brutus seria submetido a uma nova prova quando seus dois únicos filhos envolveram-se numa conspiração que objetivava devolver o poder aos Tarquínios. Presos os responsáveis, a tarefa de decidir a punição aos traidores foi delegada ao primeiro cônsul, que condenou seus filhos à morte.

Lucius Junius Brutus já havia inspirado Voltaire e Alfieri, que produziram peças teatrais sobre o personagem em 1730 e $1786.8 \mathrm{Na}$ abordagem do tema, David não se detém na execução de Tito e Tibério em praça pública, deslocando o drama para um ambiente privado e familiar contextualizado pelo longo título do quadro: Junius Brutus, primeiro cônsul, de volta à sua casa após ter condenado seus dois filhos que haviam se unido aos Tarquínios e tinham conspirado contra a liberdade romana. Os lictores trazem seus corpos para que ele thes dê sepultura (1789 - Figura 8). Como em $\bigcirc$ juramento dos Horácios, David divide Junius Brutus... em espaços bem definidos: Brutus e os lictores que carregam os cadáveres de Tito e Tibério, à esquerda; e um grupo de mulheres que dá vazão a seu desespero, à direita. A presença da loba que amamenta Rômulo e Remo, na base da imagem situada no canto inferior esquerdo do quadro, marca outra semelhança com 
os Horácios: uma representação do Estado, Roma, que se se interpõe entre o pai e os (cadáveres dos) filhos.

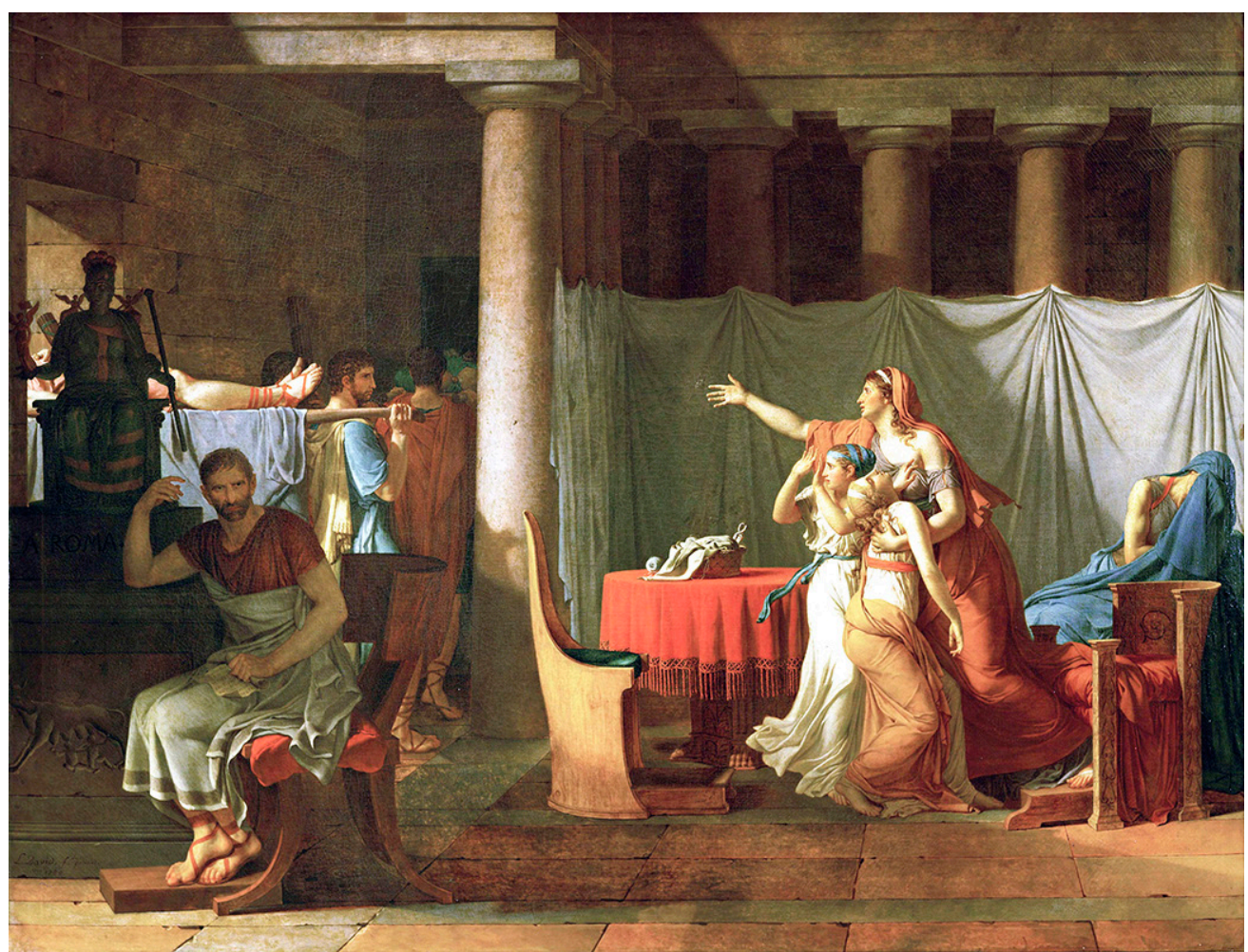

Figura 8 - Junius Brutus, primeiro cônsul, de volta à sua casa após ter condenado seus dois filhos que haviam se unido aos Tarquínios e tinham conspirado contra a liberdade romana. Os lictores trazem seus corpos para que ele thes dê sepultura. Jacques-Louis David, 1789. Óleo sobre tela, $323 \times 422$ $\mathrm{cm}$. Louvre, Paris, França.

Uma análise menos atenta pode nos levar à conclusão de que, recuperando $\bigcirc$ juramento dos Horácios, Junius Brutus... reafirma, com maior ênfase, a necessidade de os cidadãos colocarem os interesses do Estado à frente de seus pessoais. Uma análise mais acurada da obra, no entanto, parece indicar que a defesa desse princípio não é incondicional. Como já foi dito, David desloca o drama do âmbito público para o privado: o Brutus de David não é o "primeiro cônsul" que assiste à execução dos traidores de Roma em praça pública, mas o "pai" que recebe, em sua casa, o corpo dos filhos para thes dar sepultura. Derramando-se sobre a parte inferior do corpo de Brutus, a luz parece "cindi-lo" em duas partes, enfatizando o conflito desse personagem dividido. As referências utilizadas por David na composição de Brutus acentuam essa clivagem. Como destaca Simon Lee 11999, p. 122, 124), se o rosto que vemos na tela é idêntico ao do busto de Brutus do Museu do Capitólio (Figura 9), seu corpo se assemelha ao do profeta Isaías pintado por Michelangelo no teto da Capela Sistina (Figura 10): pregando a 
obediência às leis de Deus como único meio de libertar os judeus da dominação dos assírios, Isaías destacou-se pelas menções à chegada do Messias, tendo sido, segundo a tradição, serrado ao meio por ordem do rei Manasses (Hebreus, 1 1: 37). Se o Isaías de Michelangelo segura seu livro, - Brutus de David "amassa" um pergaminho que, sem conter um texto legível, é muitas vezes associado à sentença de morte dos filhos. Jean Starobinski define Junius Brutus... como a "versão romana e pagã do sacrifício de Abraão, em que nenhum anjo veio deter a mão do pai" (STAROBINSKY, 1988, p. 77). A partir da análise dos elementos anteriormente mencionados, podemos também associá-lo a Deus e seu Filho: "o Cordeiro de Deus que tira o pecado do mundo!" (João, 1: 29).

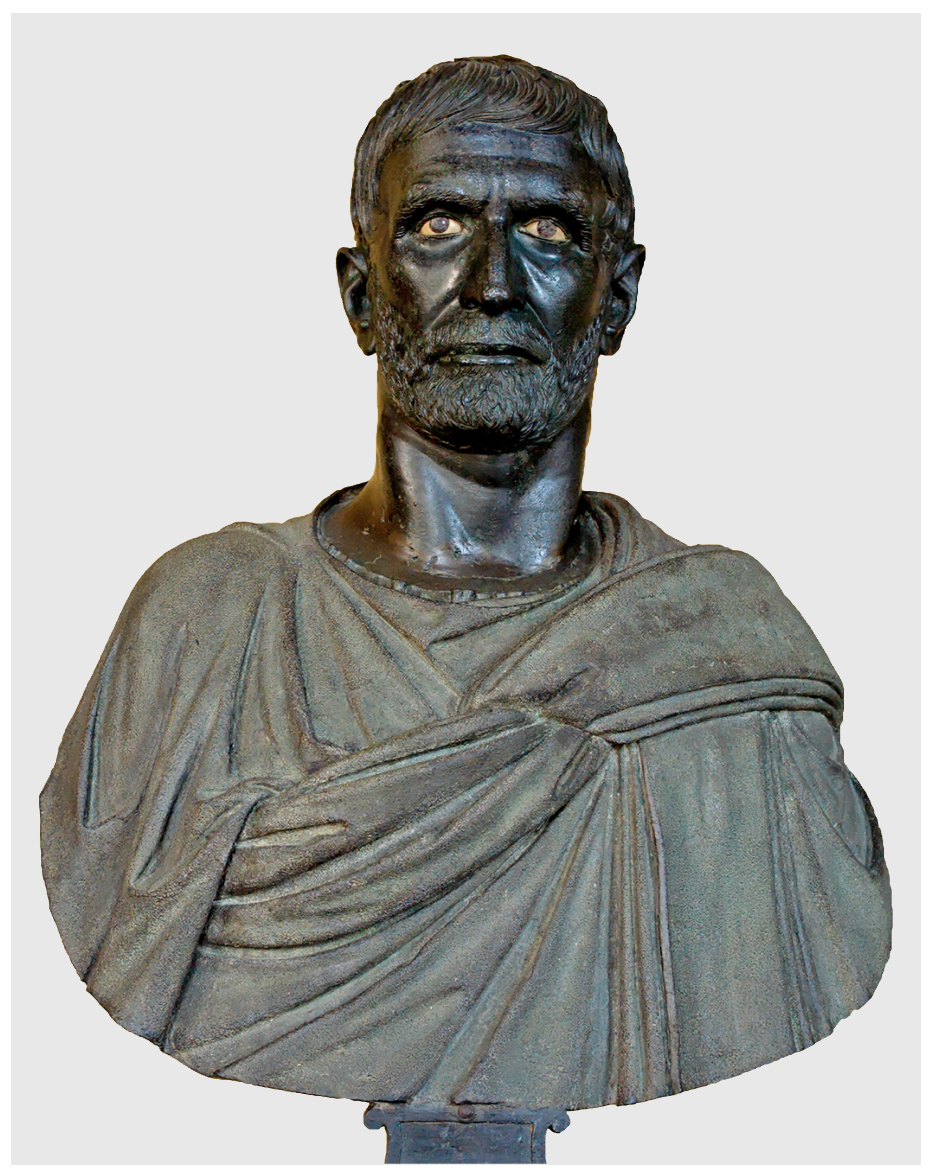

Figura 9 - Brutus. IV-III século a.C. Escultura em bronze, $69 \mathrm{~cm}$. Musei Capitolini, Roma, Itália.

Como já o havia feito com Sócrates, David imprime um caráter sagrado a Brutus. $\bigcirc$ personagem converteu-se em objeto de devoção de revolucionários (HERBERT, 1973, p. 96-1 12), que justificaram a violência e o sangue impostos à nação francesa como o preço a ser pago pela liberdade da pátria: a nova família política que deveria sobrepor-se aos laços de parentesco, ordem ou profissão. 


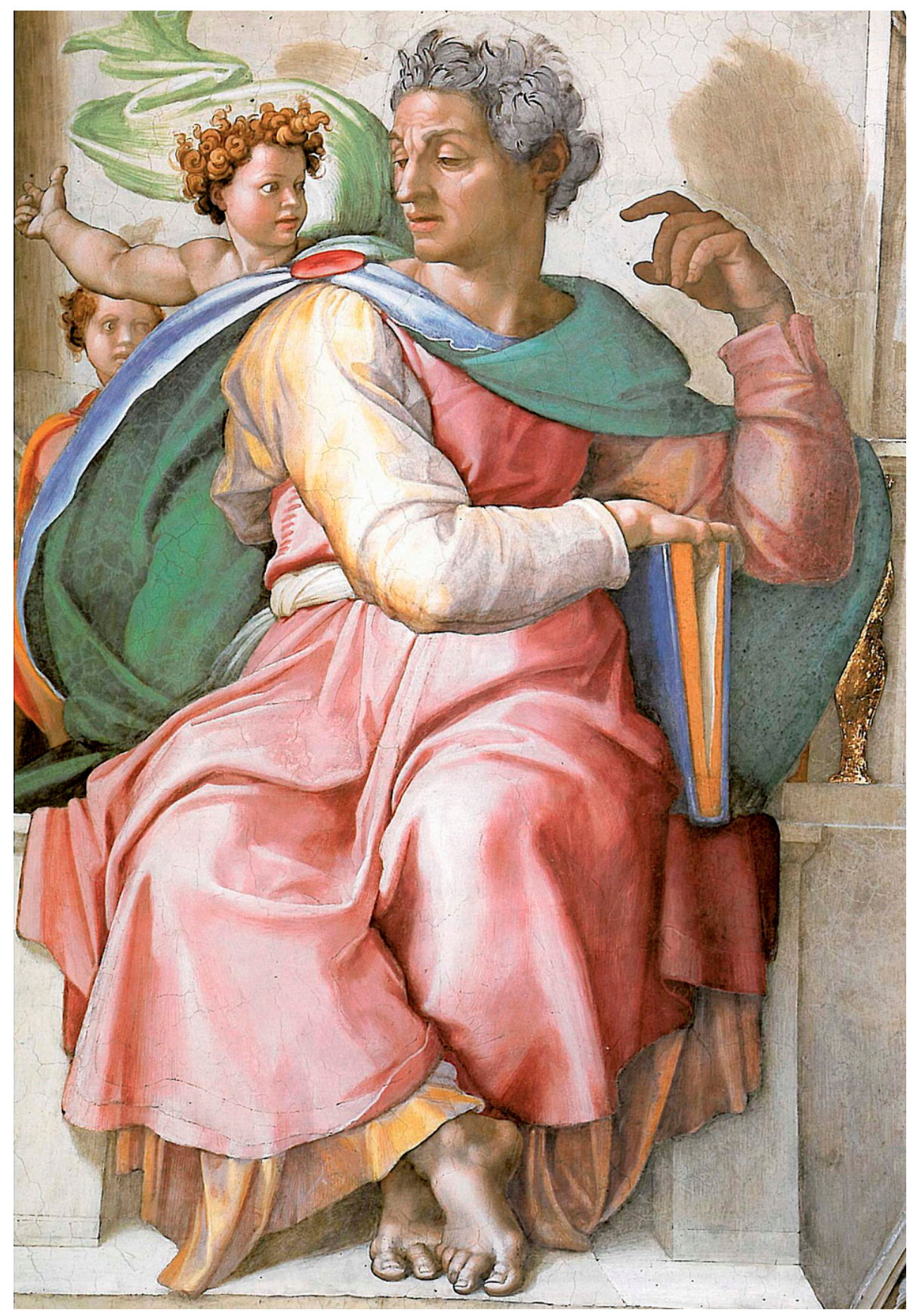

Figura 10 - Profeta Isaías. Michelangelo Buonarroti, 1508-1512. Capela Sistina, Vaticano, Itália.

Cabe destacar mais uma vez, no entanto, a tensão que se faz presente na obra: com o rosto, pés e mãos contraídos, Brutus expõe uma angústia que instiga seus observadores a questionar a legitimidade de sua decisão. Em meio às sombras, Brutus dirige seu olhar aos visitantes do Louvre, convidando-os a refletir sobre os dilemas que o perturbavam. Os fins justificam os meios? A violência quando exercida em nome de uma nação, de um Estado, de uma classe, de um povo ou de uma revolução é necessariamente legítima? Presente desde os primeiros 
momentos da Revolução Francesa, a violência só atingiu os níveis que a caracterizariam como "terror" na segunda metade do ano de 1792. Isso não impediu que, em 1789, o Junius Brutus... de Jacques-Louis David expusesse questões que, dada sua relevância, continuam angustiando os "homens comuns" e os historiadores das revoluções.

Do seu exílio na Espanha, para onde havia sido mandado por medida de segurança por Luís XVI, o conde D'Angiviller procurou impedir a exposição de Junius Brutus... e outras obras de temática mais explicitamente política no Salão de 1789. As pressões exercidas sobre os organizadores do Salão e sobre o próprio David foram respondidas pela publicação de manifestos que atacavam a "censura real" e exigiam a imediata liberação das obras "patrióticas". A polêmica contribuiu para aumentar o impacto de Junius Brutus... quando o mesmo foi exposto, duas semanas após a abertura oficial do Salão de Paris. Jacques-Louis David obteve mais uma vitória sobre adversários que perdiam poder e influência com a revolução.

\section{O juramento do jogo da pela}

Encorajado pela vitória do 14 de julho, Jacques-Louis David uniu-se a professores e alunos da Academia na elaboração de um projeto de reforma da instituição. Encarregado de apresentá-lo à Assembleia Nacional, David estreitou laços com os jacobinos, tornando-se, ele também, um membro do "clube". A Sociedade dos Amigos da Constituição era uma continuação do Clube Bretão dos deputados de Versalhes que se reunia no antigo Convento dos Jacobinos para formular estratégias de atuação na Assembleia. Com o sucesso da Revolução, o clube viu multiplicar seus sócios e "filiais" pelo território francês.

Em 28 de outubro de 1790, Dubois-Crancé ocupou a tribuna dos Jacobinos para propor que a Assembleia financiasse uma tela de Jacques-Lovis David. Um quadro "histórico" que, em detrimento de gregos e romanos, se debruçaria sobre os heroicos deputados de $O$ juramento do jogo da pela (1791 - Figura 11).

Em 20 de junho de 1789, depois de subverter as regras que deveriam pautar os Estados Gerais, os deputados da Assembleia Nacional encontraram sua sala de reuniões fechada por ordem do rei. Impedidos pela chuva de se reunir nos jardins de Versalhes, os deputados realizaram sua reunião numa quadra de jogo da pela situada próxima ao palácio, onde firmaram um juramento: nada os impediria de dar continuidade ao processo de elaboração de uma Constituição que, extinguindo o absolutismo, reorganizaria o Estado francês.

Ao mesmo tempo que evidenciavam a importância do fato no processo revolucionário, as dimensões de $\bigcirc$ juramento do jogo da pela $(7 \mathrm{~m} \times 10 \mathrm{~m}$ ) dificultavam a execução da tela: com um custo previsto em 72 mil libras, a obra deveria ser custeada por uma subscrição entre os membros do clube dos jacobinos que, em junho de 1791, havia arrecadado menos de $8 \%$ do valor total. Com o 
9. David fez questão de marcar a recusa de Dauchs retratando-o, com as mãos cruzadas sobre o peito, no canto inferior direito da tela. apoio do amigo Barère, David conseguiu que os deputados da Assembleia aprovassem o financiamento da obra pelo Tesouro público (SAHUT; MICHEL, 1988, p. 68), transferindo seu estúdio para a nave dessacralizada da lgreja dos Fueldenses: o local ficava próximo à Assembleia Nacional, facilitando que os deputados viessem a seu estúdio para a produção dos retratos e esboços que seriam utilizados na composição da tela.

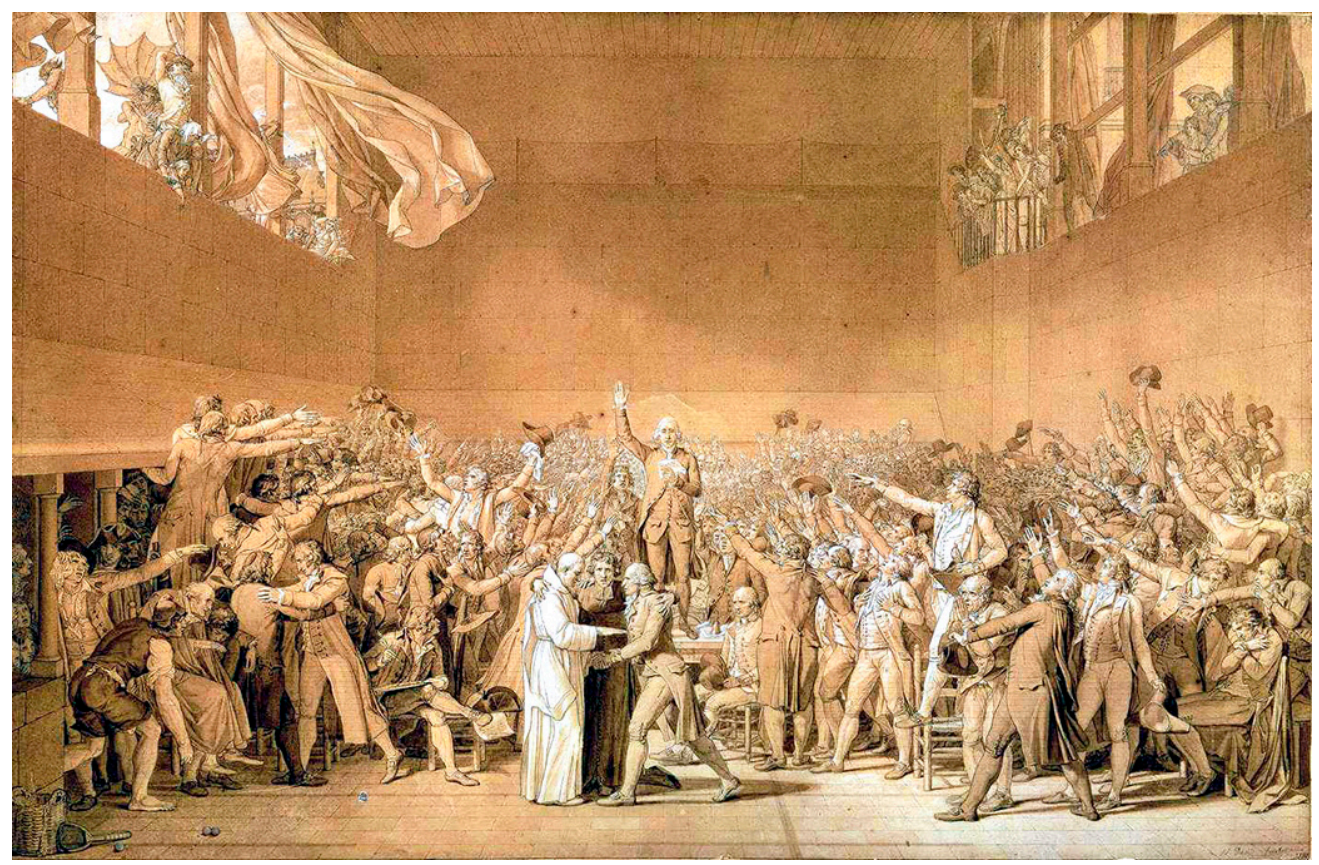

Figura 11 - O juramento do jogo da pela. Jacques-Louis David, 1791. Desenho em pena, tinta marrom, tinta preta e lápis. 66 × 101,2cm. Musée National de Château de Versailles, Versalhes, França.

Exposto no Salão de 1791, ao lado de O juramento dos Horácios, o desenho que deveria servir como modelo para a execução de $O$ juramento do jogo da pela nos permite avaliar a obra. A tela teria sua parte inferior ocupada por deputados que, à exceção de Martin Dauchs, ${ }^{9}$ expressam sua adesão ao juramento, copiando, com os braços erguidos, o gesto dos Horácios. No centro da tela, sobre a mesa que the servia de palco e tribuna, o astrônomo Bailly é o alvo preferencial dos olhares enquanto lê o texto juramentado. Abaixo de Bailly, Dom Gerle, abade Gregóire e Rabaut de Saint-Etienne representam os membros do clero regular, do clero secular e da lgreja Presbiteriana que haviam se unido à Assembleia Nacional. À direita do trio, olhando para o alto e com as mãos colocadas sobre o peito, um deputado que se consolidava como uma liderança da Assembleia Nacional: Maximilien Robespierre. A direita deste último, em plano mais próximo ao olhar do observador, Mirabeau e Barnave seguram seus chapéus tricornes.

Sem pretender retratar fielmente o fato, David encarou $O$ Juramento do jogo da pela como um pretexto para discutir a "revolução", termo que, antes de sua 
apropriação pelo vocabulário político, caracterizava um fenômeno natural: numa definição muito imprecisa, o "giro" da órbita de planetas, satélites e astros. Em seu quadro, David restabelece essa associação da revolução com as forças da natureza: ao observarmos o desenho, quase podemos sentir os ventos da tempestade que balança cortinas, vira guarda-chuvas e quase arranca o chapéu da cabeça do cidadão que, unido a outros personagens, observa o juramento por uma "janela" no canto superior esquerdo da "tela". Ao "olharmos para fora da quadra", através dessa abertura, percebemos outro detalhe significativo: um raio cai sobre o Palácio de Versalhes, anunciando como o "Antigo Regime" seria fulminado pela revolução.

Celebrada em $O$ Juramento do jogo da pela, a comunhão momentânea entre deputados de variadas tendências rapidamente se esfacelou. A realização de duas festas diferentes para comemorar o primeiro aniversário do evento expôs divisões que podem ser ilustradas a partir das trajetórias de Mirabeau, Barnave e Bailly. Ao assumir a defesa do rei, após sua malograda fuga em junho de 1791, Barnave se tornou um dos alvos principais dos republicanos que seriam massacrados no Campo de Marte por ordem de Bailly, então prefeito de Paris. A vitória do 10 de agosto de 1792 selou o destino de Barnave e Bailly, guilhotinados em novembro de 1793. Morto de causas naturais, em abril de 1791, Mirabeau não escapou da ira revolucionária quando a descoberta de um cofre secreto expôs documentos que evidenciavam sua aliança com o rei: seus despojos foram arrancados do Panteão para ceder lugar aos do "amigo do povo" Jean-Paul Marat.

Após um período de intensa dedicação à obra, na virada de 1791 para 1792, David abandonou a produção de $\bigcirc$ juramento do jogo da pela. "Ferida" por golpes de baioneta dos membros da Guarda Real suíça que se abrigaram na antiga Igreja dos Fueldenses durante os combates de 10 de agosto de 1792, a tela já havia se tornado "velha" antes mesmo de ser terminada. ${ }^{10}$

Lepeletier de Saint Fargeau

À medida que Jacques-Louis David estreitava laços com deputados "radicais", cresciam seus atritos com a esposa. Em 1791, o artista candidatou-se a um cargo na Assembleia Legislativa sem conseguir os votos necessários para ocupá-lo. O levante de 10 de agosto de 1792 marcou o rompimento definitivo do pintor com a burguesia liberal: com o apoio de Jean Paul Marat, David candidatou-se, mais uma vez, ao cargo de deputado e, uma vez eleito, tornou-se figura de destaque na Convenção Montanhesa. Seguindo o exemplo dos personagens que retratara em $\bigcirc$ juramento dos Horácios e em Junius Brutus..., o artista não hesitou em colocar os interesses da pátria à frente de seus interesses familiares: David votou pela execução de Luís XVI, indo contra a opinião da esposa que, revoltada, exigiu-lhe o divórcio. Comparada às de outros revolucionários, no entanto, essa separação era um sacrifício "menor".
10. "Por volta de 17991800, David foi obrigado a abandonar seus planos de concretizar a obra ao não conseguir suporte governamental". Depositada no Museu do Louvre e depois no estúdio de Antoine-Jean Gros, a tela inacabada foi recortada antes de ser adquirida, em 1836, pelo Estado francês. Cf. Simon Lee (1999, p. 144). 
Na noite de 20 de janeiro de 1723, véspera da execução de Luís XVI, Lepeletier de Saint Fargeau interrompeu seu jantar para atender a um desconhecido, que the perguntou se ele votara favoravelmente à execução do rei. Ao ouvir a resposta afirmativa, Philippe de Paris, antigo membro da Guarda Real, sacou uma faca, enterrando-a, seguidas vezes, no peito do deputado.

Num momento de profunda crise social, política e militar, o assassinato de Lepeletier foi habilmente utilizado pelos montanheses. Coube a Jacques-Louis David a tarefa de organizar os funerais do mártir: durante quatro dias seu corpo foi exposto na Praça Vendôme sobre o pedestal que, até 10 de agosto de 1792, sustentara uma estátua de Luís XIV. Duas escadarias permitiam aos interessados aproximar-se do cadáver que, deitado sobre um divã, expunha no peito descoberto as chagas abertas pelo punhal de Philippe de Paris. $O$ tableau ainda incluía a arma do crime, a camisa ensanguentada da vítima e uma frase atribuída ao herói: "Estou feliz por derramar meu sangue pela pátria, espero que sirva para consolidar a liberdade e a igualdade".

Com a intenção de consolidar Lepeletier como objeto de veneração dos franceses, Jacques-Louis David planejou a construção de um monumento em mármore que, dada a falta de tempo e recursos, cedeu lugar a um quadro. Destruída pela filha do homenageado, monarquista que abominava o "radicalismo" do pai, a tela Lepeletier de Saint Fargeau só pôde ser avaliada a partir de desenhos e gravuras, como a de Anatole Devosge, que reproduzem o original (Figura 12). Numa referência ao episódio clássico da Espada de Dâmocles, David faz pender sobre o cadáver uma espada sustentada por um único fio: representação da instabilidade e dos perigos enfrentados pelos revolucionários. Vertendo gotas de sangue e decorada com a flor de lis, símbolo da monarquia, a espada atravessa um bilhete onde podemos ler: "Eu voto pela morte do tirano". Num discurso pronunciado na Convenção em 29 de março de 1794, Jacques-Louis David discorreu sobre as razões que o teriam levado a produzir o quadro, apontando as "lições" que deveriam ser extraídas da tela:

[...] o verdadeiro patriota deve aproveitar qualquer oportunidade para esclarecer os cidadãos de sua comunidade, bem como mostrar-thes, constantemente, a sublime face do heroísmo e da virtude... Eu terei cumprido o meu dever se um dia [diante da tela] um velho pai, cercado por sua grande família, pronunciar as frases a seguir: "Crianças, venham e vejam o primeiro de seus representantes a morrer pela sua liberdade. Vejam como a sua face contém uma expressão de paz para que, quando vocês próprios morrerem pela pátria, possam ter plena consciência do significado de tal ato. Vocês estão vendo a espada sustentada sobre a sua cabeça por um único fio? Isso mesmo crianças, ela mostra quanta coragem foi necessária para que Michel Lepeletier e seus nobres companheiros desbaratassem o maldoso tirano que nos oprimia há tanto tempo. Se eles dessem um único passo errado, aquele fio se quebraria e eles seriam mortos. Vocês estão vendo a ferida profunda? Vocês estão chorando e desviando seu rosto para o lado crianças! Então olhem apenas para a coroa: é a coroa da imortalidade. A nação pode conferi-la a qualquer uma de suas crianças que faça por merecê-la". (DAVID apud LEE, 1999, p. 157-1581 


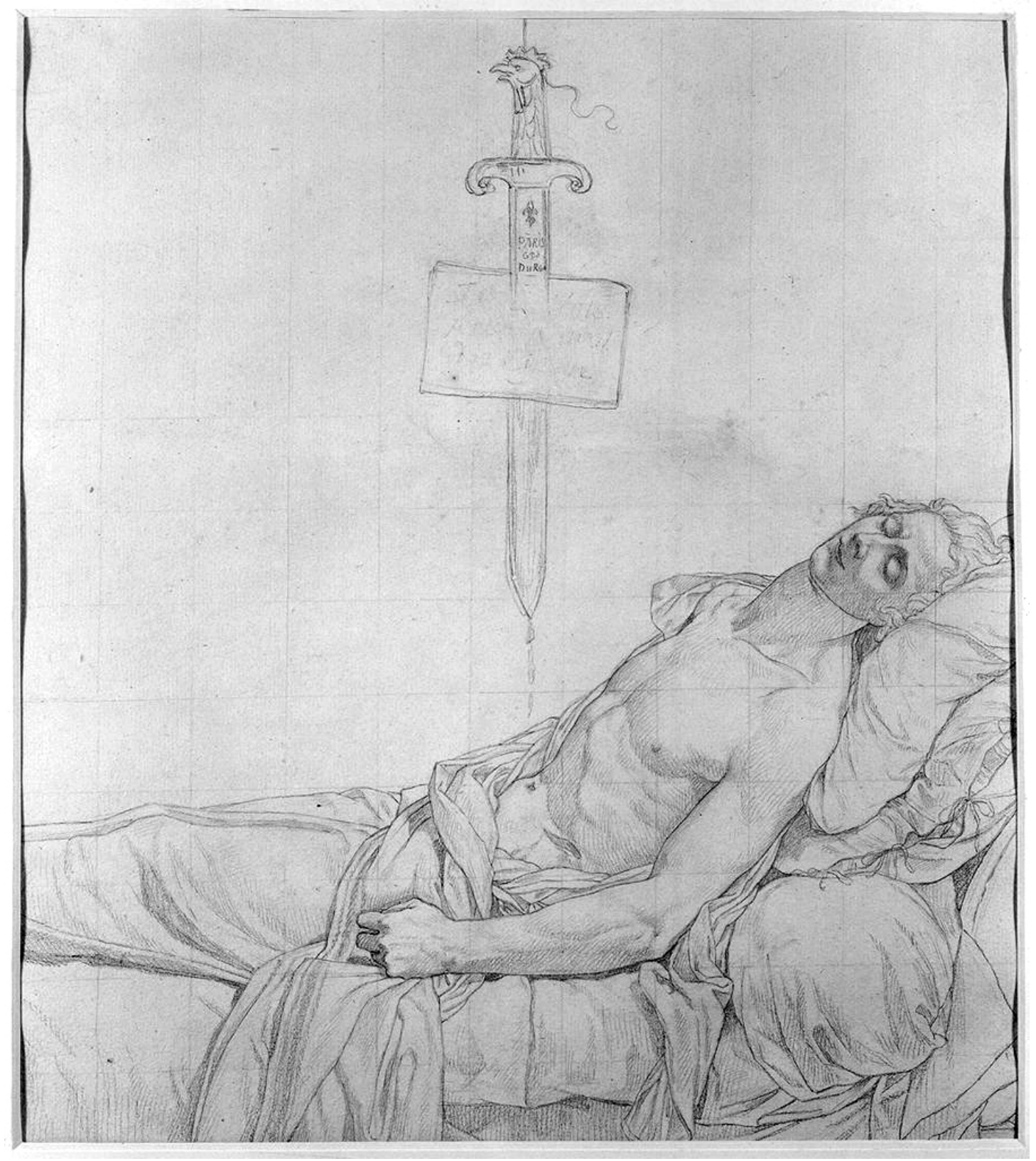

Figura 12 - Lepeletier de Saint Fargeau. Anatole Devosge, 1793. Desenho. Musée des Beaux-Arts, Dijon, França.

Completando a tríade iniciada com Patroclo e Heitor, David nos apresenta seu Aquiles. Pautados por um comportamento oposto ao de Tétis, os franceses deveriam, com o auxílio de Lepeletier de Saint Fargeau, incentivar suas "crianças" a "morrerem pela pátria". Como os aedos da Grécia Antiga, JacquesLouis David se encarregaria de celebrar seu sacrifício através da arte, garantindoIhes a "coroa da imortalidade". 
11. Sobre o assassinato de Marat e seus funerais, consultar Simon Schama (1989, p. 584-589).

\section{Marat assassinado}

Em função do agravamento de sua psoríase artrítica pelo calor do verão, Jean-Paul Marat se afastara dos debates da Convenção. Com diversas partes do corpo em carne viva, o deputado passava a maior parte do dia tomando banhos medicinais que aliviavam a dor de seus ferimentos. Ao visitar o amigo, em 12 de julho de 1793, Jacques-Louis David encontrou-o em sua banheira, fazendo anotações sobre o caixote de madeira que the servia como mesa de trabalho. Apesar da doença, Marat estava no auge de sua carreira, tendo se destacado como um dos principais líderes da Montanha na luta contra os girondinos, vitória que elevara seu prestígio entre os sans-culottes e o colocara na mira de Charlotte Corday: jovem que, talvez inspirada por Judite, rumou de Caen a Paris no encalço do seu Holofernes. ${ }^{11}$

Frustrado pela licença do deputado, o plano de matar Marat em plena Convenção foi substituído por outra estratégia. Na manhã do dia 13 de julho, Charlotte Corday procurou o líder montanhês em seu apartamento, deixando-the uma carta em que manifestava sua disposição em denunciar girondinos de sua cidade. Retornando à residência às sete da noite, Charlotte venceu a resistência de Simone Evrard, noiva e secretária do deputado, conseguindo sua tão desejada audiência. De dentro da sua banheira, Marat conversou com Charlotte sobre a situação de Caen, comprometendo-se a mandar para a guilhotina os contrarrevolucionários que ela denunciara. Durante a conversa, aproveitando um momento de distração de Simone Evrard, Charlotte sacou o punhal que comprara especialmente para a ocasião, golpeando o líder montanhês abaixo da clavícula.

Na conturbada sessão da Convenção realizada no dia seguinte ao assassinato, os deputados convocaram David a homenagear o novo mártir com um de seus quadros. O pintor aceitou a tarefa, incumbindo-se também da organização dos ritos fúnebres que, como já havia ocorrido com Lepeletier, deveriam ensejar uma grande manifestação de devoção patriótica. A tarefa era agora, no entanto, muito mais complicada: as elevadas temperaturas do mês de julho e as feridas provocadas pela psoríase artrítica trouxeram enormes dificuldades para David e para o especialista encarregado de preparar o corpo. Terminado o embalsamamento, Louis Deschamps iniciou o "embelezamento" do cadáver: disfarçou as feridas da psoríase artrítica com cosméticos e cortou a língua que "saltara" da boca do defunto quando sua cabeça foi colocada sobre um travesseiro. Coberto por pústulas e ocupando um lugar de destaque no tableau, o braço direito de Marat exigiu uma intervenção mais radical: David e Louis Deschamps substituíramno por um membro "saudável" recolhido no necrotério de Paris.

Como nos funerais de Lepeletier, o corpo de Marat foi colocado, com seu tronco exposto, sobre uma cama apoiada num pedestal. A banheira, o caixote e outros objetos relacionados à morte do personagem ajudaram a compor o cenário. Ao mesmo tempo que disfarçavam os maus odores do 
cadáver, velas e incensos contribuíam para imprimir um tom religioso à "exposição" realizada na antiga lgreja dos Cordeliers. Apesar de todos os cuidados, o evento não se desenvolveu como planejado: iniciada em 15 de julho, a exibição do corpo teve de ser interrompida na tarde do dia 16. Além do adiantado estado de putrefação do cadáver, um incidente foi determinante para seu encerramento prematuro: o horror causado por um admirador que, ao puxar a mão do líder revolucionário para homenageá-lo com um beijo, arrancou-lhe o braço postiço.

Na noite do dia 16, o corpo de Marat foi levado à cova sem o seu coração que, removido durante o processo de embalsamamento, foi colocado numa urna de ágata e pendurado na nave da lgreja dos Cordeliers. $\bigcirc$ cenário ajudava a enfatizar o caráter sagrado da "relíquia" que se tornou objeto de um discurso de Morel:

Ó coração de Jesus, ó coração de Marat [...] tendes igual direito a nossa homenagem. Ó coração de Marat, sacré coeur [...] podem as obras e a benevolência do filho de Maria serem comparadas às do Amigo do Povo e seus apóstolos aos jacobinos de nossa sagrada Montanha? [...] Seu Jesus não passava de um falso profeta, porém Marat é um Deus. Viva o coração de Marat. [...] Como Jesus, Marat amou ardentemente o povo. [...] Como Jesus, Marat abominou os nobres, os sacerdotes, os ricos, os vilões. Como Jesus, levou uma vida pobre e austera. (MOREL apud SCHAMA, 1989, p. 597-598)

Com a tela Marat assassinado (1793 - Figura 13), Jacques-Louis David deu continuidade ao processo de "sacralização" do líder revolucionário. Na banheira, imerso em seu próprio sangue, Marat expõe o ferimento provocado pela faca de Charlotte Corday. Com a cabeça envolta numa espécie de toalha e com o braço caído para fora da banheira, Marat segura, com sua mão direita, uma pena. Sua mão esquerda (sobre uma placa de madeira coberta com um tecido verde que cobre parte da banheira) segura o bilhete em que Charlotte Corday the solicitara ajuda: "Basta-me ser infeliz para ter direito a vossa benevolência". Na parte inferior esquerda do quadro, um punhal sujo de sangue revela a arma do crime. Mais à direita, sobre o caixote que the servia de mesa, elementos que procuram enfatizar a bondade do deputado e a perversão da assassina: um tinteiro, um assignat e a carta em que o "amigo do povo" justificava a concessão de favores a Charlotte Corday, "mãe de 5 filhos cujo marido havia morrido pela sua pátria".

Concluído pouco depois da adoção do "calendário republicano", Marat assassinado problematiza a superação do Antigo Regime pela revolução. Procurando enfatizar o 14 de julho de 1789 como o início de um novo tempo, deputados propuseram a adoção de um novo calendário que se iniciaria a partir do "primeiro dia da liberdade". $\bigcirc$ tema gerou polêmicas que se acirraram com o 10 de agosto de 1792: "primeiro dia da república e da igualdade". Ao cabo de acirradas discussões, a Convenção Montanhesa oficializou, em 24 de outubro de 1793, o "calendário republicano" em que o ano 1 passava a ser contado a partir 


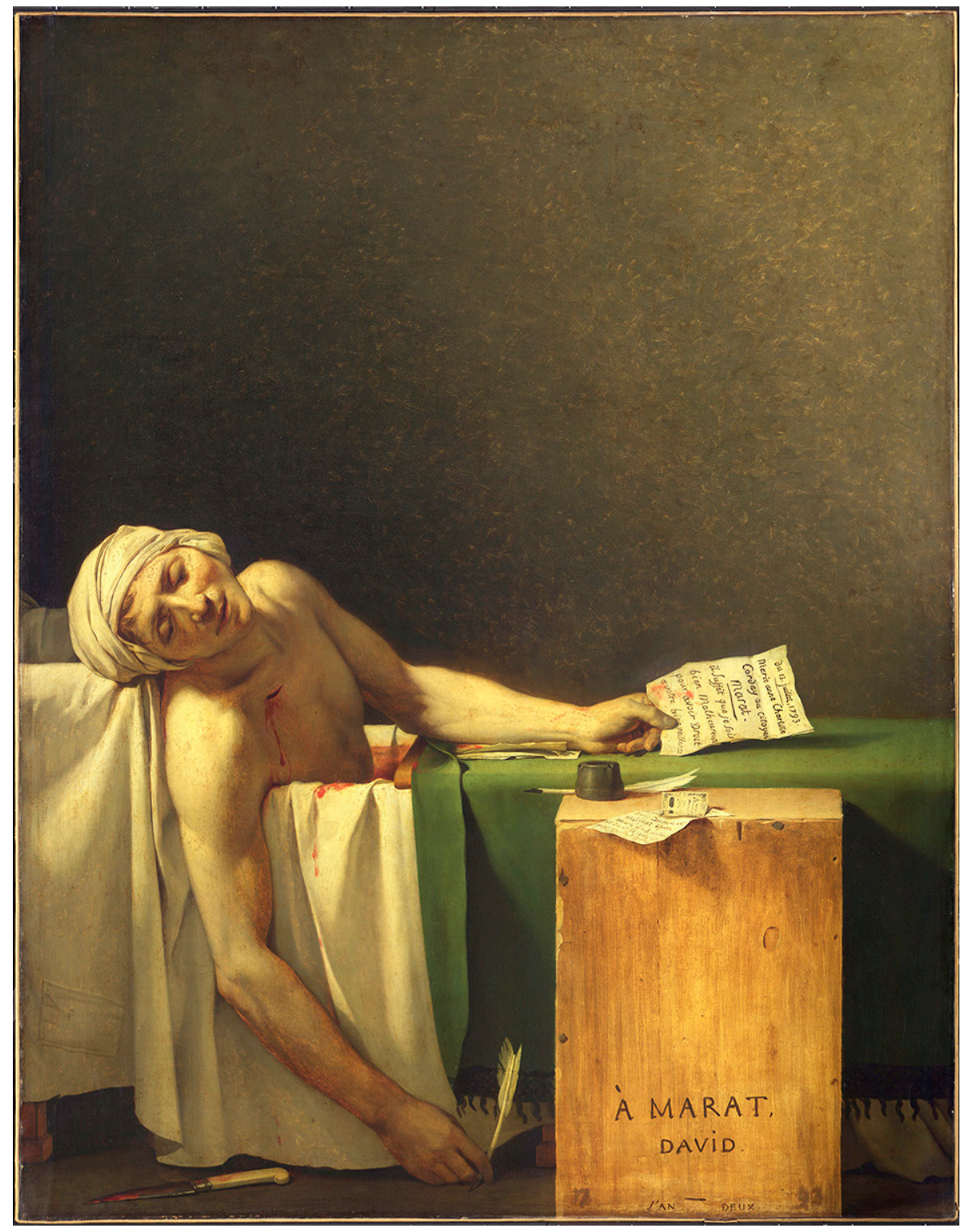

Figura 13 - Marat assassinado. JacquesLouis David, 1793. Óleo sobre tela, $165 \times 128 \mathrm{~cm}$. Musées Royaux des Beaux-Arts, Bruxelas, Bélgica.

de 22 de setembro de 1793: dia da proclamação da República que, de maneira proposital, "coincidiu" com o equinócio de outono. Rompendo com o calendário gregoriano, fundado na "superstição e no fanatismo", o calendário revolucionário adotava os elementos da natureza, os heróis e as festas revolucionárias como balizas que deveriam imprimir uma nova orientação ao cotidiano do povo francês (OZOUF, 1989). No bojo desse processo, Jacques-Louis David parece ter percebido o papel que Jean Paul Marat poderia desempenhar na consolidação da "nova era". Na carta endereçada a Marat, Charlotte Corday faz uso do calendário gregoriano, 13 de julho de 1793, em contraste com o calendário revolucionário 
utilizado por David na dedicatória do quadro. Exposta na parte frontal da "mesa de trabalho" do deputado, a indicação "L'AN DEUX", marco do novo tempo, é inserida entre "17" e "93": resquícios de uma era de desigualdade que, como os números gravados na base do caixote, dissolvia-se com o advento da revolução.

Verbalizado nos funerais do líder montanhês e no discurso de Morel, o projeto de equiparar Jean-Paul Marat a Jesus Cristo deixou marcas profundas em Marat assassinado. A comparação de Marat assassinado com as Pietás de Giovanni Belinni ou de Michelangelo evidencia semelhanças que não são acidentais: a posição do braço direito, os ferimentos no tórax, os tecidos que envolvem os corpos e a expressão de tranquilidade no rosto dos cadáveres. Num momento em que o combate à lgreja resultara no fechamento de templos e na proibição de missas e outras manifestações de culto público, Jacques-Lovis David dava sua contribuição para a construção de uma "religião revolucionária", em que os mártires da liberdade substituiriam Jesus Cristo, a Virgem Maria e outras divindades como objetos de culto do povo francês.

\section{REFERÊNCIAS}

BELTING, Hans. Image et culte: une histoire de l' art avant l'époque de l'art. Paris, Cerf, 1998.

BÍBLIA SAGRADA. Rio de Janeiro: Barsa, 1964.

BLAKE, Nigel; FRASCINA, Francis. As práticas modernas da arte e da modernidade. In: FRASCINA, Francis et al. Modernidade e Modernismo: a pintura francesa no século XIX. São Paulo: Cosac Naify, 1998.

BLOCH, Marc. Os reis taumaturgos. São Paulo: Companhia das Letras, 1998.

BURKE, Peter. A fabricação do rei: a construção da imagem pública de Luís XIV. Rio de Janeiro: Zahar, 1994.

CLARK, Timothy James. A pintura do Ano II. In: Modernismos. São Paulo: Cosac Naify, 2007.

DESSOLDI, Flávia Giovana. Da tela ao palco: pintura, teatro e revolução no Brutus de JacquesLouis David. Sala Preta, São Paulo: USP - PPGAC, v. 15, n. 1, p. 265 a 275, 2015.

FORTES, Luiz Roberto Salinas. O Iluminismo e os reis filósofos. São Paulo: Brasiliense, 1981. 
FURET, François. Pensando a Revolução Francesa. Rio de Janeiro: Paz e Terra, 1989.

; OZOUF, Mona. Dicionário crítico da Revolução Francesa. Rio de Janeiro: Nova Fronteira, 1989.

HERBERT, Robert L. David, Voltaire, Brutus and the French Revolution: an essay in art and politics. New York: Viking Press, 1973.

HOBSBAWN, Eric J. A era das revoluções: 1789/1848. Rio de Janeiro: Paz e Terra, 1982.

LEE, Simon. David. London: Phaidon, 1999.

OZOUF, Mona. Calendário. In: FURET, François; OZOUF, Mona. Dicionário crítico da Revolução Francesa. Rio de Janeiro: Nova Fronteira, 1989. p. 465-474.

PELIKAN, Jaroslav. Jesus ao longo dos séculos. São Paulo: Cosac Naify, 2000.

ROBERTS, Warren. Jacques Louis David, revolutionary artist: Art, Politics, and the French Revolution. Chapel Hill: University of North Caroline Press, 1989.

RUSCONI, Carlos. Dicionário do Grego do Novo Testamento. São Paulo: Paulus, 2005.

SAHUT, Marie-Catherine; MICHEL, Régis. David: l'art et le politique. Paris: Gallimard, 1988.

SCHAMA, Simon. Registrando a Revolução: David. In: O poder da arte. São Paulo: Companhia das Letras, 2010.

Cidadãos: uma crônica da Revolução Francesa. São Paulo: Companhia das Letras, 1989.

SCHWARCZ, Lilia Moritz. O sol do Brasil. São Paulo: Companhia das Letras, 2008.

SOBOUL, Albert. A Revolução Francesa. Rio de Janeiro: Zahar, 1964.

STAROBINSKY, Jean. 1789: os emblemas da Razão. São Paulo: Companhia das Letras, 1988.

VERNANT, Jean Pierre. A bela morte e o cadáver ultrajado. Discurso, n. 9, p. 31, 1978. Disponível em: <http://www.revistas.usp.br/discurso/article/view/37846/40573>, acesso em agosto de 2016.

VOVELLE, Michel. França Revolucionária: 1789/1799. São Paulo: Brasiliense, 1989.

WINCKELMANN, Johan Joachim. Reflexões sobre a Arte Antiga. Porto Alegre: Movimento/ Universidade Federal do Rio Grande do Sul, 1975.

Artigo apresentado em 30/06/2016. Aprovado em 02/01/2017. 